\title{
Dioxomolybdenum (VI) and Oxomolybdenum (IV) Complexes With N, O, and S Bidentate Ligands, Spectral Characterization, and DFT Studies
}

Othman Ibrahim Alajrawy ( $\square$ othman_ibraheem2000@yahoo.com ) University of Fallujah https://orcid.org/0000-0002-3509-6060

Ayad A. Almhmdi

University of Anbar

\section{Research Article}

Keywords: Molybdenum(IV) complexes, Molybdenum(VI) complexes, 2- hydrazinopyridine, dithiooxamide, spectroscopic, theoretical calculations

Posted Date: September 22nd, 2021

DOl: https://doi.org/10.21203/rs.3.rs-872772/v1

License: (c) (i) This work is licensed under a Creative Commons Attribution 4.0 International License.

Read Full License 


\section{Abstract}

Two dioxomolybdenum (VI) complexes with chemical formula $\left[\mathrm{MoO}_{2}(\mathrm{acac})(\mathrm{HPY})\right]$, and $\left[\mathrm{MoO}_{2}(\mathrm{DTO})\right.$ (HPY)], with another two oxomolybdenum (IV) complexes [MoO(acac)(HPY)], and [MoO(DTO)(HPY)] have been prepared and characterized by different spectral techniques such as (FTIR, UV-Vis., Mass, ${ }^{1} \mathrm{H}-\mathrm{NMR}$ ) spectra, magnetic susceptibility, and theoretical studies. The bidetentate ligands used in this study were acetylacetone (acac), 2-hydrazinopyridine (HPY), and dithiooximid (DTO). All the spectroscopic data and the theoretical calculations support the suggestion that the dioxomolybdenum(VI) complexes are diamagnetic and have distorted octahedral structures wheras the oxomolybdenum(IV) complexes are paramagnetic and have distorted square pyramidal structures. Theoretical calculations of the free ligands and the prepared complexes have been done by using DFT calculations by using (GAUSSian $09 W$ ) software with basis sets (B3YLP/LanL2DZ). The complexes were very stable and their energies ranged from (-708.85 to -921.99 a.u.) and were very different from that of the free (HPY, DTO) ligands (-359.06 and -984.54 a.u.); respectivily. The prepared complexes are polar (8.11-10.80 Debye) for dioxocomplexes(VI), and (6.63-13.72 Debye) for oxocomplexes(IV), its more than the free (HPY and DT0) ligands (1.46-1.67 Debye); respectivly. The HOMO orbitals energies of the dioxocomplexes(VI) are (-0.229, and -0.377 a.u.), respectivily whereas oxocomplexes(IV) are $(-0.192,-0.318$ a.u.); respectivily while for the ligands are $(-0.216,-0.262$ a.u. $)$, respectivily. The LUMO orbitals energies of the dioxocomplexes( $\mathrm{VI})$ are $(-0.124$, and -0.247 a.u. $)$ and for the oxocomplexes are $(-0.093,-0.208$ a.u. $)$ its obvouse that they are more lower in their energies than that for the (HPY and DTO) ligands.

\section{Introduction}

Molybdenum is an essential trace element required in most biological systems [1]. It has many oxidation states (II-VI), the oxidation states (II, III, IV, and V) are air sensitive. The salts of molybdenum are more stable due to its being durability, toughness, and hardness, it was made them alloys and steel [2]. Water can contain another amount of different concentrations from molybdenum and on the other hand, humans, animals, and plants include a vital trace element from molybdenum [3]. The most important oxidation states of molybdenum are (IV) and (VI) states during the binding and reactions. A stable oxomolybdenum(IV) complexes are comparatively scarce than their dioxomolybdenum ( $\mathrm{VI}$ ) coordinate and structurally characterized oxomolybdenum (IV) complexes are excessively rare [4]. The importance of molybdenum complexes in the medicinal applications of dental caries, enhancement of immunological reaction, anticancer and antidiabetic agents, therapeutic, medicinal immense and its effect on different enzymes [5]. Molybdenum can be given oxidation state in oxo complex so determined by the number of oxo groups that to join in center atom [6]. Molybdenum play as a cofactor in three enzyme called molybdoenzymes. This molybdoenzymes has an oxo-group that to believe to responsible for the oxo transferase activity in this enzyme. The oxo-group includes a molybdenum center that can be coordinated by two or more $\mathrm{S}$ and $\mathrm{N}$ donor ligand [7]. Molybdenum( $\mathrm{VI})$ complexes include a cis- $\mathrm{MoO}_{2}$ unit that has worked the same as enzyme-like xanthine oxidase and nitrogenase, the complexes are contained a $\mathrm{Mo}=$ $\mathrm{O}$ unit used as catalysts in the industry because of oxygen atom transfer reactions [8]. The discovery of 
the presence of NSO donor points around the $\mathrm{Mo}(\mathrm{VI})$ center of oxotransferase enzymes like xanthine oxidase and DMSO reductase led to the synthesis and exploration of the oxo transferability of model complexes that mimic the oxotransferase molybdoenzymes [9]. Dithiooximide (DTO) is an external active agent with varied coordination chemistry due to the intense color character, (DTO) can be used in photographic processes, coordination polymers, and histological agents. (DTO) complexes in transition metals have properties as semiconductor, spectroscopic and magnetic [10]. (DTO) has a long history of use as a reagent for the detection and determination of more transition metals due to the presence of two parts of the thioamide in this class of compounds, it plays an important role in chemotherapy because a large number of biologically active compounds contain this part $(-\mathrm{N}-\mathrm{C}=\mathrm{S})$ [11]. Dioxomolybdenum(VI) complexes with bi-donor ligands and polydonor atoms such as $\mathrm{O}$ and $\mathrm{N}$ and ligands with donor sets $\mathrm{O} 2 \mathrm{~N}$, $\mathrm{O} 2 \mathrm{~N}, \mathrm{SO} 2 \mathrm{~N}$, or $\mathrm{S} 2 \mathrm{~N}$ can catalyze oxo-atom transfer reactions. $\mathrm{Mo}(\mathrm{VI})$ complexes with 2-hydroxyarylidene thiosemicarbazones having N2O or ONS donor sets have important results in biological activity tests [11]. Other complexes of $\mathrm{Mo}(\mathrm{VI})$ with aroylhydrazone ligands containing a cis $\left[\mathrm{MoO}_{2}\right]^{2+}$ core have been prepared and extensively studied due to their structural flexibility, facile preparation, and their stability. Mononuclear dioxomolybdenum(VI) complexes $\left[\mathrm{MoO}_{2} \mathrm{LB}\right]\left[\mathrm{H}_{2} \mathrm{~L}=\right.$ 2-aminobenzoylhydrazone of benzoyl acetone have been prepared and investigated [12]. $\mathrm{Mo}(\mathrm{VI})$ complexes are potential as an anti-diabetic agent but didn't have an understanding of $\mathrm{Mo}(\mathrm{VI})$ speciation in biological media. The complex speciation in aqueous solutions of molybdate is further underscored by the formation of several oligomeric species, conversion among oxidation states, and rapidly exchanging forms. This property gives the $\mathrm{Mo}(\mathrm{VI})$ complexes to be insulin-mimetic candidates and this can be explained as a result of reversible inhibition of phosphate-dependent enzymes by $\left[\mathrm{MoO}_{4}\right]^{2-}$, similar to that of vanadate ion, or due to the irreversible oxidation of phosphatases by $\mathrm{Mo}(\mathrm{VI})$ peroxido complexes similar to $\mathrm{V}(\mathrm{V})$ peroxido complexes [13]. $\mathrm{Mo}(\mathrm{VI})$ complex of picolinic acid-based metallomicellar catalyst was used in the controlled and chemoselective oxidation of the activated alcohols in the aqueous medium. Interesting metathetic oxidation of 2-butene to acetaldehyde by $\mathrm{O}_{2}$ gas catalyzed by the immobilized $\mathrm{MoO}_{2}$-hydrazone complexes on $\mathrm{SiO}_{2}$ afforded high yields. The heterogeneous molybdenum-salicylidene 2-picoloyl hydrazone complex, which supported on $\mathrm{Fe}_{3} \mathrm{O}_{4}$ nano-particles, showed high catalytic potential in the (ep)oxidation of various olefins. Molybdenum acetylacetonate complexes, which are supported on functionalized nano-particles, investigated as catalysts in the (ep)oxidation of unsaturated hydrocarbons presenting high potential. Dioxomolybdenum( $\mathrm{VI})$ complexes as durable and highly efficient precatalysts for alkene epoxidation, were investigated recently by Mösch-Zanetti et al. [14]. Mo(VI) with unsaturated bidentate sulfur ligands complexes have been prepared and investigated. The $\mathrm{Mo}(\mathrm{VI})$ complexes such as tris-(benzene-1,2-dithiolate) molybdenum give stable species [Mo(BDT) $\left.{ }_{3}\right]$, which are neutral for $[\mathrm{Mo}(\mathrm{VI})]$, $[\mathrm{Mo}(\mathrm{V})]^{-1}$ and $[\mathrm{Mo}(\mathrm{IV})]^{-2}[15]$. The present study is the destination to prepare and characterize $\mathrm{Mo}(\mathrm{IV})$, and $\mathrm{Mo}(\mathrm{VI})$ ternary complexes with dioxygen, ditholene, and dinitrogen donor atoms ligands. The reactions of the bidentate ligands with bis-(acetylacetonate) dioxomolybdenum $(\mathrm{VI})$ gave the complexes. The structures and NBO charges of 2-hydrazinopyridne (HPY) and dithiooxamide (DTO) ligands are depicted in Fig. 1. Our research group is engage with the preparation and characterization of molybdenum and vanadium complexes in different oxidation states because of their biological activity, many industrial 
uses, and important role in medicinal chemistry so this complexes will be inter in different applications in the future studies.

\section{Experimental}

\subsection{Materials}

The chemicals were in high purity, 2-hydrazinopyridine (HPY) (95\%) was purchased from Fluka. Sodium molybdate dihydrate $\left(\mathrm{Na}_{2} \mathrm{MoO}_{4} \cdot 2 \mathrm{H}_{2} \mathrm{O}\right)$ and dithiooxamide (DTO) were purchased from Aldrich. Solvents were of analytical grade. The starting complex $\left[\mathrm{MoO}_{2}(\mathrm{acac})_{2}\right]$ was prepared as described in the literature [16-17].

\subsection{Measurements}

Infrared measurements of the 2-hydrazinopyridine (HPY), dithiooxamide (DTO) ligands, and the complexes, as $\mathrm{KBr}$ pellets, were carried out using a Bruker Tensor $27 \mathrm{FT}$-IR spectrophotometer in the range 4000-400 $\mathrm{cm}^{-1}$. ${ }^{1} \mathrm{H}-\mathrm{NMR}$ was recorded using ultra shield Bruker $500 \mathrm{MHNMR}$ at $\left({ }^{1} \mathrm{H}\right.$ at $\left.500 \mathrm{MHz}\right)$. Mass spectrometry measurements were carried out using GCMS-QP1000EX. The magnetic susceptibility of the complexes was carried out using a Balance Magnetic Susceptibility Model (MSB-MKI). UV-Vis. spectra were recorded in a $1.0 \mathrm{~cm}$ path length quartz cell by using a UV-Vis. spectrophotometer type Shimadzu UV-1800 UV-Vis. in DMSO. The structures of the 2-hydrazinopyridine (HPY), dithiooxamide (DTO) ligands, and the complexes were optimized by the use of [GAUSSIAN 09W] software program at the B3LYP/LanL2DZ basis sets for the complexes and B3LYP/6-31G $(d, P)$ for the ligands.

\subsection{Preparation of dioxomolybdenum(VI) complexes}

\subsection{1. $\left[\mathrm{MoO}_{2}(\mathrm{acac})(\mathrm{HPY})\right]$ complex}

The $\left[\mathrm{MoO}_{2}(\mathrm{acac})_{2}\right]$ precursor salt has been prepared by the literature method [16-17]. The $\left[\mathrm{MoO}_{2}(\mathrm{acac})_{2}\right]$ $(0.30 \mathrm{~g}, 1 \mathrm{mmol})$, and $(0.11 \mathrm{~g}, 1.0 \mathrm{mmol})$ of 2-hydrazinopyridine (HPY) ligand have been mixed dropwise with constant stirring and refluxed for two hours. The color of the solution changed from yellow to brown and obtained a precipitate. The precipitate was filtered and washed several times with ethanol and finally with diethyl ether and kept in dissector for $24 \mathrm{hrs}$. The complex have been subjected to elemental analysis: : Anal. Calc. for; $\left(\mathrm{C}_{10} \mathrm{H}_{15} \mathrm{MoN}_{3} \mathrm{O}_{4}\right)$, Calc.: $\mathrm{C}, 35.62 ; \mathrm{H}, 4.48 ; \mathrm{N}, 12.46$, Found: $\mathrm{C}, 35.43 ; \mathrm{H}, 4.36$; N, 12.19\%); m.p >300 C ; Scheme 1 .

\subsection{2. $\left[\mathrm{MoO}_{2}\right.$ (DTO)(HPY)] complex}

The $\left[\mathrm{MoO}_{2}(\mathrm{acac})_{2}\right](0.30 \mathrm{~g}, 1 \mathrm{mmol})$, and $(0.12 \mathrm{~g}, 1.0 \mathrm{mmol})$ of dithiooxamide (DTO) ligand have been mixed dropwise with constant stirring and refluxed for two hours. The color of the solution changed from yellow to dark brown and obtained a precipitate. The precipitate was filtered and washed several times with ethanol and finally with diethyl ether and kept in dissector for $24 \mathrm{hrs}$. The complex have been 
subjected to elemental analysis: Anal. Calc. for; $\left(\mathrm{C}_{7} \mathrm{H}_{11} \mathrm{MoN}_{5} \mathrm{O}_{2} \mathrm{~S}_{2}\right)$, Calc.: $\mathrm{C}, 23.53 ; \mathrm{H}, 3.10 ; \mathrm{N}, 19.60$, Found: $C, 23.29 ; H, 2.89 ; N, 19.39 \%) ; m . p ~>300 ~ C$; Scheme 2 .

\subsection{Preparation of oxomolybdenum(IV) complexes}

\subsection{1. [MoO(acac)(HPY)] complex}

$(0.3 \mathrm{~g}, 1 \mathrm{mmol})$ of $\left[\mathrm{MoO}_{2}(\mathrm{acac})_{2}\right]$ was dissolved in $20 \mathrm{ml}$ of absolute ethanol, then $(0.11 \mathrm{~g}, 1.0 \mathrm{mmol})$ of 2-hydrazinopyridine (HPY) had been added dropwise to a stirred solution, and $(0.262 \mathrm{~g}, 1 \mathrm{mmol})$ of triphenylphosphine was added slowly with constant stirring. After two hours dark brown precipitate isolated washed several times with ethanol and finally with diethyl ether and kept in dissector for $24 \mathrm{hrs}$. The complex have been subjected to elemental analysis: Anal. Calc. for; $\left(\mathrm{C}_{10} \mathrm{H}_{15} \mathrm{MoN}_{3} \mathrm{O}_{3}\right), \mathrm{Calc}$.: $\mathrm{C}, 37.40$; $H, 4.71 ; N, 13.08$, Found: $C, 37.19 ; H, 4.59 ; N, 12.89 \%) ; m . p>300 C^{\circ}$; Scheme 3.

\subsection{2. [MoO(DTO)(HPY)] complex}

$(0.3 \mathrm{~g}, 1 \mathrm{mmol})$ of $\left[\mathrm{MoO}_{2}(\mathrm{acac})_{2}\right]$ was dissolved in $20 \mathrm{ml}$ of absolute ethanol, and $(0.12 \mathrm{~g}, 1.0 \mathrm{mmol})$ of dithiooxamide (DTO) dissolved in $20 \mathrm{ml}$ of acetone had been added dropwise to a stirred solution, then $(0.11 \mathrm{~g}, 1.0 \mathrm{mmol})$ of 2-hydrazinopyridine (HPY), and finally $(0.262 \mathrm{~g}, 1 \mathrm{mmol})$ of triphenylphosphine was added slowly with constant stirring. After two hours light brown precipitate isolated washed several times with ethanol and finally with diethyl ether and kept in dissector for $24 \mathrm{hrs}$. The complex have been subjected to elemental analysis: Anal. Calc. for; $\left(\mathrm{C}_{7} \mathrm{H}_{11} \mathrm{MoN}_{5} \mathrm{OS}_{2}\right)$, Calc.: $\mathrm{C}, 24.64 ; \mathrm{H}, 3.25 ; \mathrm{N}, 20.52$, Found: C, 24.42; H, 3.09; N, 19.89\%); m.p >300 C ; Scheme 4 .

\section{Results And Discussion}

The physical and electronic transitions of the complexes are presented in Table 1.

\subsection{FT-IR spectra.}

The FT-IR spectral data of the complexes are illustrated in Table 2. The peaks of the complexes were compared with that of the free 2-hydrazinopyridine (HPY) and free dithiooxamide (DTO) ligands to monitor the variations in the frequencies of the coordination sites. The spectrum of the free 2-

hydrazinopyridine (HPY) ligand showed bands at $\left(3395,3308 \mathrm{~cm}^{-1}\right)$ which are assigned to the stretching vibrations asymmetrical and symmetrical of the amine groups. The spectrum of the $\left[\mathrm{MoO}_{2}(\mathrm{acac})\right.$ (HPY)] complex showed broad bands at $\left(3089,3016 \mathrm{~cm}^{-1}\right)$ attributed to asymmetrical and symmetrical $\left(\mathrm{NH}_{2}\right)$ stretching frequencies; respectively. This is an indication of the coordination between the 2hydrazinopyridine (HPY) ligand and the $\mathrm{Mo}(\mathrm{VI})$ ion through the nitrogen atoms of the amine groups. The band at $1600 \mathrm{~cm}^{-1}$ vibration was assigned for the $\mathrm{v}(\mathrm{C}=0)$ stretching frequency in (acac). The spectrum exhibited new bands at $\left(921,1110 \mathrm{~cm}^{-1}\right)$ that can be attributed to symmetric and asymmetric stretching of $\mathrm{U}(\mathrm{O}=\mathrm{Mo}=0)$ in cis-configuration [18-19]. The spectrum of the $\left[\mathrm{MoO}_{2}(\mathrm{DTO})(\mathrm{HPY})\right]$ complex is illustrated 
in Fig. 2 showed broad bands at $\left(3618,3047 \mathrm{~cm}^{-1}\right)$ attributed to asymmetrical and symmetrical $\left(\mathrm{NH}_{2}\right)$ stretching; respectively [19]. This is confirmed the coordination between the 2-hydeazinopyridine (HPY) ligand and the Mo ion through the nitrogen atoms of the amine groups. The complex with (DTO) spectrum also exhibited a new band at $\left(953,1153 \mathrm{~cm}^{-1}\right)$ that can be attributed to symmetric and asymmetric stretching of $\mathrm{U}(\mathrm{O}=\mathrm{Mo}=0)$ in cis-configuration $[11,19]$. The thioamide group stretching three bands have appeared in this complex at $\left(1527,1423\right.$, and $\left.1191 \mathrm{~cm}^{-1}\right)$, this confirms the coordination of the (DTO) ligand to the Mo ion [11]. The spectrum of the [MoO(acac)(HPY)] complex showed broad bands at $\left(3606,3101 \mathrm{~cm}^{-1}\right)$ attributed to asymmetrical and symmetrical $\left(\mathrm{NH}_{2}\right)$ stretching; respectively. The band at $1519 \mathrm{~cm}^{-1}$ assigned for the vibrations of $\mathrm{u}(\mathrm{C}=0)$ in (acac). The spectrum showed a band at $\left(952 \mathrm{~cm}^{-1}\right)$ this band refers to the $\mathrm{v}(\mathrm{Mo}=0)$ stretching. The spectrum of the [MoO(DTO(HPY)] complex showed broad bands at $\left(3738,3603 \mathrm{~cm}^{-1}\right)$ attributed to asymmetrical and symmetrical $\left(\mathrm{NH}_{2}\right)$ stretching. The thioamide group stretching three bands have appeared in this complex at $\left(1519,1427\right.$, and $\left.1172 \mathrm{~cm}^{-1}\right)$, this confirms the coordination of the (DTO) ligand to the Mo ion [11]. The spectrum showed a band at the range $\left(952 \mathrm{~cm}^{-1}\right)$ which refers to the $\mathrm{v}(\mathrm{Mo}=0)$ stretching [18-19]. The $\mathrm{M}$ $\mathrm{N}, \mathrm{M}-\mathrm{O}$, and M-S bands appeared in the complexes at $\left(450-467 \mathrm{~cm}^{-1}, 487-510 \mathrm{~cm}^{-1}\right.$, and $\left.570-585 \mathrm{~cm}^{-1}\right)$; respectively $[12,21-22]$. The experimental FT-IR data of the dioxomolybdenum and oxomolybdenum complexes were compared with the calculated data of optimized complexes structure obtained from the DFT calculation by using (Gaussian 09W software) and it was without any negative value that and it's in good agreement with the experimental ones. The differences between the experimental and the calculated data due to the different methods used to obtain them.

\subsection{Mass spectral analysis}

The mass spectra of the complexes exhibited the main mass fragmentation peaks which are listed in Table 3. Mass spectrum of the complex $\left[\mathrm{MoO}_{2}\right.$ (acac)(HPY)] (molecular weight 339.01) gave molecular ion peak $(M)$ at $\mathrm{m} / \mathrm{z}=338.40$, a peak at $\mathrm{m} / \mathrm{z}=238.23$ assigned for $(\mathrm{M}$-acac), a peak at $\mathrm{m} / \mathrm{z}=$ 230.94 assigned for (M-HPY), a peak at $\mathrm{m} / \mathrm{z}=130.16$ attributed to $\left(\mathrm{MoO}_{2}\right)$. The spectrum showed also peaks at $\mathrm{m} / \mathrm{z}=95.08,96.0$, and 96.79 which are assigned to the stable molybdenum isotopes. Mass spectrum of the complex $\left[\mathrm{MoO}_{2}\right.$ (DTO)(HPY)] (molecular weight equals 358.94) gave molecular ion peak (M) at $\mathrm{m} / \mathrm{z}=(356.66)$, a peak at $\mathrm{m} / \mathrm{z}=250.40$ assigned for (M-HPY), a peak at $\mathrm{m} / \mathrm{z}=235.59$ assigned for (M-DTO), a peak at $\mathrm{m} / \mathrm{z}=129.26$ assigned for $\left(\mathrm{MoO}_{2}\right)$, a peak at $\mathrm{m} / \mathrm{z}=119.89$ assigned for (DTO), a peak at $m / z=110.76$ assigned for (HPY) ligand. The spectrum showed also peaks at $m / z=97.41,98.86$, and 101.37 which are assigned to the stable molybdenum isotopes. Mass spectrum of the [MoO(acac) (HPY)] complex (molecular weight 323.02) gave molecular ion peak (M) at $m / z=323.09$, a peak at $\mathrm{m} / \mathrm{z}=227.14$ assigned for (M-acac), a peak at $\mathrm{m} / \mathrm{z}=215.01$ assigned for (M-HPY), a peak at $\mathrm{m} / \mathrm{z}=115.64$ attributed to (MoO). The spectrum showed also peaks at $m / z=95.08,96.0$, and 96.79 which are assigned to the stable molybdenum isotopes. Mass spectrum of the [MoO(DTO)(HPY)] complex (molecular weight equals 342.95) gave molecular ion peak $(M)$ at $m / z=(340.25)$, a peak at $m / z=225.93$ assigned for (MDTO), a peak at $m / z=235.15$ assigned for (M-HPY), a peak at $m / z=113.26$ assigned for (MoO), a peak at 
$\mathrm{m} / \mathrm{z}=121.19$ assigned for (DTO), a peak at $\mathrm{m} / \mathrm{z}=111.96$ assigned for (HPY) ligand. The spectrum of the complex showed also a peak at $\mathrm{m} / \mathrm{z}=99.05$, which is assigned to the stable molybdenum isotope [23]. The mass spectrum data of the $\left[\mathrm{MoO}_{2}\right.$ (DTO)(HPY)] complex is presented in Fig. $\mathbf{3}$ as a represented example. The data of mass spectra for the complexes are presented in (SI).

\section{3 ${ }^{1} \mathrm{H}-\mathrm{NMR}$ spectra}

The ${ }^{1} \mathrm{H}-\mathrm{NMR}$ spectral data for the free ligands and $\mathrm{Mo}(\mathrm{VI})$ complexes in DMSO-d ${ }^{6}$ are presented in Table 4. The experimental data compared with the calculated spectra that obtained from the DFT calculations. The ${ }^{1} \mathrm{H}$-NMR spectrum of the 2-hydrazinopyridine (HPY) ligand showed the signals at the range $(\delta=7.38$ $8.504 \mathrm{H}) \mathrm{ppm}$ are assigned to the pyridine group protons as multiple peaks. The characteristic signal at $(\delta=4.36 \mathrm{H}) \mathrm{ppm}$ is assigned to the $\mathrm{NH}$ proton as a single peak. The signal at $(\delta=3.662 \mathrm{H}) \mathrm{ppm}$ is assigned to the $\mathrm{NH}_{2}$ proton as a single peak. The ${ }^{1} \mathrm{H}-\mathrm{NMR}$ spectrum of the $\left[\mathrm{MoO}_{2}(\mathrm{acac})(\mathrm{HPY})\right]$ complex showed the signal at the range $(7.8-8.74 \mathrm{H}, \mathrm{s}) \mathrm{ppm}$ assigned to pyridine group protons as multiple peaks. The signal at $(\delta=6.1 \mathrm{H}) \mathrm{ppm}$ is assigned to $\mathrm{CH}$ for the enol form of $(\mathrm{acac})$, a peak at $(\delta=3.342 \mathrm{H})$ as a singlet peak which is assigned to $\mathrm{NH}_{2}$ protons, and also peak at $(\delta=1.346 \mathrm{H}) \mathrm{ppm}$ as a singlet peak which is assigned to $\mathrm{CH}_{3}$ of (acac) ligand. The ${ }^{1} \mathrm{H}-\mathrm{NMR}$ spectrum of the $\left[\mathrm{MoO}_{2}\right.$ (DTO)(HPY)] complex showed signals at the range $(\delta=7.15-8.464 \mathrm{H}) \mathrm{ppm}$ which are assigned to the pyridine group protons as multiple peaks. The signals at $(\delta=9.69-10.21) \mathrm{ppm}$ are assigned to $\mathrm{NH}_{2}$-DTO. The signal at $(\delta=2.23-3.37) \mathrm{ppm}$ is assigned to $\mathrm{NH}_{2}$ protons as a singlet peak, which is shifted to downfield from those of the free 2hydrazinopyridine (HPY) ligand. The signal at $(\delta=4.21-4.30 \mathrm{H}) \mathrm{ppm}$ can be assigned for the NH. These data indicate that the 2-hydrazinopyridine (HPY) ligand coordinates with molybdenum(VI) atom by two nitrogen atoms of the $\mathrm{NH}_{2}$ groups and with the dithiooxamide (DTO) ligand by the two sulfur atoms. The calculated ${ }^{1} \mathrm{H}$-NMR data of the Mo(VI) complexes by use of DFT/LanL2DZ basis set were compared with the experimental data and it is in good agreement with the experimental data; Fig. 4 shows the experimental and calculated ${ }^{1} \mathrm{H}-\mathrm{NMR}$ spectra of $\left[\mathrm{MoO}_{2}(\mathrm{DTO})(\mathrm{HPY})\right]$ complexes $[15,24]$.

\subsection{Electronic spectra}

The electronic spectral data of the complexes in the DMSO solutions were recorded in the $200-1100 \mathrm{~nm}$ Table 1 and compared with the calculated spectra obtained from the TD-DFT calculations in DMSO as solvent. The experimental UV-Vis. and calculated spectra of the $\left[\mathrm{MoO}_{2}\right.$ (DTO)(HPY)] complexes are given in Fig. 5. The absorption spectrum showed peaks at $(281$, and $325 \mathrm{~nm})$, which can be assigned to $\left(\pi-\pi^{*}\right)$ and $\left(n-\pi^{*}\right)$ of the intra-ligand electronic transitions. These peaks were shifted to lower wavenumbers when compared with the peak of free ligands. The spectrum also exhibited a peak at (438 nm) assigned to $L M C T$ from $L(p \pi) \rightarrow d_{M o}$. The spectrum of the $\left[\mathrm{MoO}_{2}(\right.$ acac)(HPY)] complex showed peaks at (296, and $386 \mathrm{~nm})$, which can be assigned to $\left(\pi-\pi^{*}\right)$ and $\left(n-\pi^{\star}\right)$ of the intra-ligand electronic transitions. These peaks were shifted to lower wavenumbers when compared with the peak of free ligands. The spectrum also exhibited a peak at $(407 \mathrm{~nm})$ assigned to LMCT LMCT from $L(p \pi) \rightarrow d_{\text {Mo }}(S I)$. UV-Vis. spectra of the $[\mathrm{MoO}(\mathrm{acac})(\mathrm{HPY})]$ and [MoO(DTO(HPY)] complexes are given in (SI). The absorption spectra showed 
peaks at (270-268, and 318-369 nm); respectively which can be assigned to $\left(\pi-\pi^{\star}\right)$ and $\left(n-\pi^{\star}\right)$ of the intraligand electronic transitions. The spectra exhibited peaks at the range (440, and $447 \mathrm{~nm})$ assigned to LMCT from $L(p \pi) \rightarrow d_{\text {Mo }}$. The d-d electronic transitions within the octahedral arrangement around $\mathrm{Mo}(\mathrm{VI})$ ( $\mathrm{d}^{0}$-configuration) have vanished whereas for Mo(IV) ( $\mathrm{d}^{2}$-configuration) observed as a weak band at the range (637 and $704 \mathrm{~nm}$ ); respectively $[12,25]$. The experimental UV-Vis. data of the prepared complexes have been compared with the calculated ones by using of TD-DFT/LanL2DZ basis set in DMSO as solevent. There were acceptable differences between the experimental and the calculated data due to the different ways used to determine each one; solid-state for the experimental data and gaseous state for the calculated data.

\subsection{Magnetic measurements}

The magnetic measurement of the prepared complexes showed that the $\mathrm{Mo}(\mathrm{VI})$ complexes were diamagnetic with $d^{0}$ configuration whereas the Mo(IV) complexes were paramagnetic with $d^{2}\left(t_{2 g}{ }^{2}, e_{g}{ }^{0}\right)$ electronic configuration and the values of the $\mu_{\text {eff }}$ for the complexes are (2.9 and 3.1) $\left[\mathrm{MoO}_{2}(\mathrm{acac})(\mathrm{HPY})\right]$ and $\left[\mathrm{MoO}_{2}(\mathrm{DTO})(\mathrm{HPY})\right]$; respectivily[26].

\subsection{Theoretical studies}

The optimized structures of the 2-hydrazinopyridine (HPY), dithiooxamide (DTO) ligands, dioxomolybdenum (VI), and oxomolybdenum(IV) complexes were carried out by using the B3LYP/LanL2DZ basis sets $[27,28]$. The complexes structure with natural bond order (NBO) charges of the molybdenum and binding sites atoms are given in Fig. 6. Selected bond angles and bond lengths are given in Table 5. In $\mathrm{Mo}(\mathrm{VI})$ complexes the angles between $\mathrm{Mo}(\mathrm{VI})$ atoms and the surrounded atoms are ranged from 71.51 to 107.51 which suggests the distorted octahedral geometry for the complexes [15, 29]. The (N-Mo-N) bonds angle ranged from 71.51 to 72.58 , it deviated from the perfect octahedral structure, which supports the suggestion of the distortion in the structure of the complexes. The bond lengths between the $\mathrm{Mo}(\mathrm{VI})$ atoms and the nitrogen atoms in the complexes are (2.18-2.44 $\left.\mathrm{A}^{\circ}\right)$. The $\mathrm{Mo}=0$ bonds length are $\left(1.72 \mathrm{~A}^{\circ}\right)$, angles with cis-configuration of $(\mathrm{O}=\mathrm{Mo}=0)$ are in the range $\left(106.74^{\circ}-107.51^{\circ}\right)$ and the angles contain the oxygen, and nitrogen atoms are in the range $\left(81.33^{\circ}-89.55^{\circ}\right)$, whereas the angle between the two sulfur atoms and $\mathrm{Mo}(\mathrm{VI})$ is $\left(81.49^{\circ}\right)$. The Mo-S bonds length are $\left(2.45-2.65 \mathrm{~A}^{\circ}\right)$ and the angle contains the sulfur and nitrogen atoms is $\left(89.55^{\circ}\right)$. These angles are compared with the reported $\mathrm{Mo}(\mathrm{VI})$ complexes havd been prepared prevously, the values are consistent with the values reported (2.43) [31]. Atomic charges are very important to conclude and expected the donor and acceptor atoms in the (HPY) and (DTO) ligands and molybdenum [25, 31]. The charge densities are on the nitrogen atoms in the 2-hydrazinopyridine (HPY) and on the sulfur atoms in the dithiooxamide ligands. Molybdenum with it hexavalent coordinate and positive charge in the complexes acts as the acceptor of the charge. This is a ligand to metal charge transfer (LMCT) from the $\pi$ orbitals of the (HPY) and (DTO) ligands to the $\mathrm{Mo}_{d}$ orbital. The Mo(VI) complexes are more polarized than the (HPY) and (DTO) ligands, the dipole moments of the complexes are (8.11-10.80 Debye), whereas for (HPY) and (DTO) are (1.46 and 1.67 Debye); respectively [32-34]. In Mo(IV) complexes the 
angles between $\mathrm{Mo}(\mathrm{IV})$ atoms and the surrounded atoms are $\left(74.85^{\circ}\right.$ to $\left.110.61^{\circ}\right)$ which suggests the distorted square pyramidal geometry for the Mo(IV) complexes [35]. The (N-Mo-N) bond angles are $\left(74.85^{\circ}-77.18^{\circ}\right)$ deviated from the perfect square pyramidal structure and the bond lengths between the $\mathrm{Mo}(\mathrm{IV})$ atom and the nitrogen atoms in the complexes are $\left(2.12-2.24 \mathrm{~A}^{\circ}\right)$. The $\mathrm{Mo}=0$ bond lengths are in the range (1.70-1.71 $\left.\mathrm{A}^{\circ}\right)$ for the two complexes, these data have been compared with the reported oxomolybdenum(IV) complexes, and the values are consistent with the value reported (1.68) [36]. The angles contain the oxygen, and nitrogen atoms are in the range $\left(80.10^{\circ}\right.$ to $\left.90.39^{\circ}\right)$, whereas the angles between the two sulfur atoms and $\mathrm{Mo}(\mathrm{IV})$ is $\left(85.30^{\circ}\right)$. The Mo(IV) complexes are more polarized than the ligands as indicated from the values of the dipole moments values of the complexes (6.36-13.72 Debye) $[33-34,37]$. The electronic energy, the atomic charges, and the dipole moments of the ligands, and the complexes are tabulated in Table 6. According to (NBO) analysis for $\mathrm{Mo}(\mathrm{VI})$ complexes the electronic configuration of $\mathrm{Mo}$ in the $\left[\mathrm{MoO}_{2}\right.$ (acac)(HPY)] complex are:[core] $5 s^{0.21} 4 \mathrm{~d}^{4.05} 5 \mathrm{p}^{0.47} 5 \mathrm{~d}^{0.05}, 35.968$ core electrons, 4.732 valence electrons and 0.055 Rydberg electrons, which gives 40.755 total electrons and +0.556 e charge on Mo atom. The occupancies of $4 d$ in orbitals are $d_{x y} 0.824 ; d_{x z} 0.829 ; d_{y z} 0.867 ; d_{x}^{2}$. $y^{2} 0.741$ and $d_{z}^{2} 0.785$. The $4 d$-electron populations (4.046) are in agreement with the charge transfer from (HPY) and (acac) ligands to $\mathrm{d}_{\mathrm{Mo}}$. The electronic configuration of the complex $\left[\mathrm{MoO}_{2}\right.$ (DTO) (HPY)] are: [core] $5 s^{0.27} 4 d^{4.45} 5 p^{0.68} 5 d^{0.06}, 35.974$ core electrons, 5.460 valence electrons and 0.067 Rydberg electrons, which gives 41.501 total electrons and +0.556 e charge on Mo atom. The occupancies of $4 d$ orbitals are $d_{x y} 0.857 ; d_{x z} 0.901 ; d_{y z} 0.824 ; d_{x-y}^{2}{ }^{2} 1.013$ and $d_{z}^{2} 0.857$. The $4 d$-electron populations (4.453) are in agreement with the charge transfer from (DTO) and (HPY) ligands to $d_{M 0}$. The oxomolybdenum Mo(IV) complexes, the electronic configuration of [MoO(acac)(HPY)] complex are: [core] $5 s^{0.17} 4 d^{4.391} 5 p^{0.24} 5 d^{0.03} 6 p^{0.11}, 35.963$ core electrons, 4.911 valence electrons and 0.032 Rydberg electrons, which gives 40.906 total electrons and +1.092 e charge on Mo atom. The occupancies of $4 \mathrm{~d}$ orbitals are $d_{x y} 1.035 ; d_{x z} 0.677 ; d_{y z} 0.650 ; d_{x-y}^{2}{ }^{2} 1.355$ and $d_{z}^{2} 0.671$. The $4 d$-electron populations of 4.388 are in agreement with (HPY) and (acac) ligands to $d_{\text {Mo }}$ electron transfer [38]. The electronic configurations of $[\mathrm{MoO}(\mathrm{DTO})(\mathrm{HPY})]$ complex are: [core] $5 \mathrm{~s}^{0.25} 4 \mathrm{~d}^{4.91} 5 \mathrm{p}^{0.19} 5 \mathrm{~d}^{0.04} 6 \mathrm{p}^{0.37}, 35.968$ core electrons, 5.713 valence electrons and 0.040 Rydberg electrons, which gives 41.721 total electrons and +0.276 e charge on Mo atom. The occupancies of $4 d$ orbitals are $d_{x y} 1.166 ; d_{x z} 0.756 ; d_{y z} 0.760 ; d_{x}{ }^{2}$. $y^{2} 1.492$ and $d_{z}{ }^{2} 0.729$. The $4 d$-electron populations of 4.903 are in agreement with (HPY) and (DTO) ligands to $d_{M o}$ electron transfer. The electronic energies of the $\mathrm{Mo}(\mathrm{VI})$ complexes are $(-784.07$ and -921.99 a.u.); respectively and for the Mo(IV) complexes are (-708.85 and -846.76 a.u.); respectively these values indicate the stability of dioxomolybdenum complexes are more than the oxomolybdenum complexes [38]. HOMO and LUMO orbitals energies of the complexes are given in Table 6. The hardness $(\eta=(I-A) / 2)$ where $(I-A)=\Delta E=H O M O-L U M O$ energy levels. The $\eta$ values and $\Delta \mathrm{E}$ are given in Table 6 . The transitions of electrons are easier in the $\mathrm{Mo}(\mathrm{VI})$ complexes than the ligands which are indicated from $\Delta \mathrm{E}$ of the $\mathrm{Mo}(\mathrm{VI})$ complexes (0.105-0.130) whereas for the (HPY) and (DTO) ligands are (0.124 and 0.191); respectively [39-43]. The $\mathrm{Mo}(\mathrm{VI})$ complexes are softer $(n=(0.052-0.065)$ than the ligands also $(0.062-$ 0.095) [44]. The transitions are also easier in the $\mathrm{Mo}(\mathrm{IV})$ complexes than the ligands $\Delta \mathrm{E}$ of the Mo(IV) 
complexes are (0.099-0.110) [42]. The Mo(IV) complexes are softer $(\eta=(0.045-0.055)$ than the ligands also [43]. The negative values of the energies for the HOMO orbitals and the LUMO orbitals in the Mo(VI) and $\mathrm{Mo}(\mathrm{IV})$ complexes support the suggestion of their stability [39]. The surface plots of the HOMO and LUMO orbitals for (HPY), (DTO) ligands, Mo(VI), and Mo(IV) complexes are presented in Figs. 7 and 8. The transition energies of the complexes have been calculated from (time-dependent density functional linear response theory) Table 7. The density of the electrons in the (HPY) ligand is localized on the pyridine part and on the nitrogen atoms which may point to a mixed $\pi \rightarrow \pi^{\star}$ and $n \rightarrow \pi^{\star}$ transitions, whereas for the (DTO) ligand the red regions are on the sulfur atoms and the blue regions are on the nitrogen atoms [39]. The HOMO energies $(\mathrm{H}$ to H-4), \% of the contribution, and the main characters of (HPY), (DTO) ligands, and the molybdenum are calculated for the complexes and tabulated in Table 8. In the $\left[\mathrm{MoO}_{2}\right.$ (acac)(HPY)] complex, \% contribution of (HPY) to the HOMOs $(\mathrm{H}$ to $\mathrm{H}-4)$ in the range from $3 \%$ to $99 \%$ with the main character is HPY $(\pi)$. The \% contribution of (HPY) to LUMOs ( $L$ to $L+4)$ is lower (6\%-13\%) (except L+4 90\%). The \% contribution of the (acac) ligand to the HOMOs is low and varies from $0 \%$ to $7 \%$ (except $\mathrm{H}-190 \%$ and $\mathrm{H}-2$ 86\%) through acac( $\pi$ ) as the main character. The (acac) ligand $\%$ contribution to LUMOs is higher than its contribution to HOMOs and varied from $1 \%$ to $18 \%$ through $\operatorname{acac}\left(\pi^{*}\right)$ (except $L+369 \%$ ). The Mo \% contribution to the HOMOs varied from $0 \%$ to $4 \%$, whereas, the \% contribution of Mo to the LUMOs varied from $19 \%$ to $54 \%(L+47 \%)$ by Mo $\left(e_{g}\right)$, which states the possibility of LMCT from $\mathrm{O}(\pi)$ and/or coordinated ligands to $\mathrm{Mo}\left(\mathrm{e}_{\mathrm{g}}\right)[12,32-34]$. In the [MoO(acac)(HPY)] complex, \% contribution of (HPY) to the HOMOs $(\mathrm{H}$ to $\mathrm{H}-4)$, ranged from $4 \%$ to $83 \%$ with the main character is $\operatorname{HPY}(\pi)$. The \% contribution of (HPY) to LUMOs ( $L$ to $L+4)$ is higher $(13 \%-87 \%)$. The \% contribution of the (acac) ligand to the HOMOs is from $12 \%$ to $85 \%$ through acac $(\pi)$ as the main character. The (acac) ligand \% contribution to LUMOs is lower than its contribution to HOMOs and varied from $2 \%$ to $28 \%$ through acac $\left(\pi^{\star}\right)$ (except $L+132 \%$ ). The Mo \% contribution to the HOMOs varied from $1 \%$ to $6 \%$ (except H 74\%) whereas, the \% contribution of Mo to the LUMOs varied from $9 \%$ to $49 \%$ by Mo( $e_{g}$ ), which support the possibility of LMCT from $\mathrm{O}(\pi)$ and/or coordinated ligands to $\mathrm{Mo}\left(\mathrm{e}_{\mathrm{g}}\right)$. The $\mathrm{Mo}(\mathrm{VI})$ and $\mathrm{Mo}(\mathrm{IV})$ complexes with (DTO) ligand instead of (acac) ligand, the \% of (DTO) ligand in HOMOs are much higher than Mo and (HPY). On the other hand, the LUMOs are mainly concentrated on the Mo atoms, which support the LMCT transitions. The \% contribution and the main characters of Mo, (acac), (HPY), and (DTO) ligands to the different HOMO and LUMO orbitals in the Mo(VI) complexes are presented in Table 8. The molecular electrostatic potential (MEP) for the ligands and the complexes have been calculated and shown in Fig. $\mathbf{9}$, the red regions represent an electrophilic reactivity and the blue regions represent a nucleophilic reactivity. The nitrogen atoms of the (HPY) and the sulfur atoms in the (DTO) ligands; with their red regions (negative charge) are the reactive sites for the electrophilic attack, this constitutes the high electronegativity of the two atoms [32-34, 39]. The red regions in the complexes are mainly localized over the oxygen and sulfur atoms.

\section{Conclusion}

The synthesized $\mathrm{Mo}(\mathrm{VI})$ complexes have distorted octahedral and $\mathrm{Mo}(\mathrm{IV})$ have distorted square pyramidal geometries; the 2-hydrazinopyridine (HPY) and dithiooxamide (DTO) ligands behave as 
bidentate $\mathrm{N} 2$ donor ligand and as bidentate $\mathrm{S} 2$ donor ligand; respectively by relying on spectroscopic data, and DFT theoretical calculations. The mass spectral data showed that the molybdenum(VI) complexes and molybdenum(IV) complexes are mononuclear. The magnetic susceptibility measurements indicate that the $\mathrm{Mo}(\mathrm{VI})$ complexes are diamagnetic with $\mathrm{d}^{0}$ configuration and $\mathrm{Mo}(\mathrm{IV})$ are paramagnetic with $d^{2}$ configuration. UV-Vis. measurements showed the peaks of the charge transfer and the $(d-d)$ metal transitions. The energies of the HOMO and LUMO orbitals of the ligands and the complexes are negative which indicates that the ligands stable and the complexes are more stable.

\section{Abbreviations}

LMCT Ligand metal charge transfer

DMSO Dimethyl sulphoxide

IR

Infrared spectroscopy

DFT Density functional theory

B3LYP Becke's three-parameter exchange with Lee, Yang, and Parr correlation functional

$\eta$

The hardness

TD-DFT

Time-dependent density functional theory

HOMO

High occupied a molecular orbital

LUMO

Low occupied a molecular orbital

MEP Molecular electronic potential

$\mathrm{PPh}_{3} \quad$ Triphenylphosphine

acac Acetylacetone

HPY 2-Hydrazinopyridine

DTO Dithiooximide

\section{References}

1. A.T. -Odularu, A. Peter, Ajibade, Z. Johannes, Mbese. "Impact of molybdenum compounds as anticancer agents. Bioinorganic chemistry and applications 2019, 6416198 (2019)

2. S.K. -Patil, M. Vinayak, Naik, B. Nirmalkumar, Mallur, "Synthesis, spectral and antibacterial studies of oxomolybdenum (V) and dioxomolybdenum (VI) complexes with 2- 
imidazolyImercaptoacetohydrazone.". Der Pharma Chemica 4, 1812-1818 (2012)

3. H.-J. -Lunk, and Hans Hartl. "Discovery, properties, and applications of molybdenum and its compounds." ChemTexts 3.3 (2017): 13

4. P. -Bhattacharya, S.R. Tomar, Misra, M. Hussain. "Nutritional aspects of essential trace elements in oral health and disease: an extensive review." Scientifica 2016 (2016).5464373

5. -http://www.imoa.info/download_files/molybdenum/Applications_Mo_Metal.pdf

6. U. -Ndagi, N. Mhlongo, E. Mahmoud Soliman. "Metal complexes in cancer therapy-an update from drug design perspective." Drug design, development, and therapy 11 (2017): 599

7. H. -Mahmoudi et al., "Synthesis and X-ray Crystal Structure of a Molybdenum (VI) Schiff Base Complex: Design of a New Catalytic System for Sustainable Olefin Epoxidation." Inorganica Chimica $\operatorname{Acta}(2020): 119775$

8. A. -Dupe et al., Dioxomolybdenum ( $\mathrm{VI})$ and tungsten $(\mathrm{VI})$ complexes with multidentate aminobisphenol ligands as catalysts for olefin epoxidation. Eur. J. Inorg. Chem. 21, 3572-3579 (2015)

9. K. -Saraswati, R. Kant, Synthesis, characterization and biological activity of some molybdenum (VI) complexes. Der Pharma Chemica 5, 347-356 (2013)

10. R.J. -Muhyedeen, Bahjat, A.A. Ali Drea. "synthesis and identification of Pd (II) and Ni (II) dithiooxamide complexes." part I: Experimental (2014), 1-19

11. A.J. -Abdulghani, M. Nada, Abbas. "synthesis characterization and biological Activity study of New Schiff and mannich bases and some metal complexes derived from isatin and dithiooxamide. Bioinorganic chemistry and applications 2011, 706262 (2011)

12. D. -Biswal et al., New polymeric, dimeric and mononuclear dioxidomolybdenum (VI) complexes with an ONO donor ligand: crystal structures, DFT calculations, catalytic performance and protein binding study of the ligand. New J. Chem. 41(10), 4116-4137 (2017)

13. A. -Levina, D.C. Crans, A. Peter, Lay. "Speciation of metal drugs, supplements and toxins in media and bodily fluids controls in vitro activities. Coord. Chem. Rev. 352, 473-498 (2017)

14. M. -Adam, S. Shaker et al., Bis-dioxomolybdenum (VI) oxalyldihydrazone complexes: Synthesis, characterization, DFT studies, catalytic epoxidation potential, molecular modeling and biological evaluations. Appl. Organomet. Chem. 34(5), 5573 (2020)

15. R. -Colorado-Peralta et al. "Structural study of molybdenum (VI) complexes containing bidentate ligands: Synthesis, characterization and DFT calculations." Polyhedron 48.1 (2012): 72-79

16. J.J. -Grace J.W. Chen, McDonald, and W.E. Newton, "Synthesis of molybdenum(IV) and molybdenum(V) complexes using oxo abstraction by phosphines. Mechanistic implications" Inorg. Chem. 1976, 15, 11, 2612-2615

17. S. -Gupta et al. "Oxomolybdenum (VI) and (IV) complexes of pyrazole derived ONO donor ligandssynthesis, crystal structure studies and spectroelectrochemical correlation." Polyhedron 26.1 (2007): 133-141 
18. -Kazuo Nakamoto, Infrared and Raman Spectra of Inorganic and Coordination Compounds, Part B, Applications in Coordination, Organometallic and Bioinorganic Chemistry (John Wiley \& Sons, 2009)

19. -Cis-Dioxido-molybdenum( $\mathrm{VI})$ complexes of tridentate ONO hydrazone Schiff base: Synthesis, characterization, X-ray crystal structure, DFT calculation and catalytic activity, Inorg. Chemica. Acta. $2015,427,52-61$

20. P. -Neves et al., Synthesis, structure and catalytic olefin epoxidation activity of a dinuclear oxobridged oxodiperoxomolybdenum ( $\mathrm{VI}$ ) complex containing coordinated 4, 4'-bipyridinium. Molecular Catalysis 432, 104-114 (2017)

21. S. -Ebrahimipour, Yousef et al., "cis-Dioxido-molybdenum (VI) complexes of tridentate ONO hydrazone Schiff base: Synthesis, characterization, X-ray crystal structure, DFT calculation and catalytic activity.". Inorg. Chim. Acta 427, 52-61 (2015)

22. D. -Biswal et al., Lewis base controlled supramolecular architectures via non-covalent interactions of dioxomolybdenum (vi) complexes with an ONS donor ligand: DFT calculations and biological study. New J. Chem. 39(4), 2778-2794 (2015)

23. -R.P. Bush, Platinum Met. Rev. 35(4), 202 (1991)

24. S. -Raghvendra, N. Sengar, Victor, Nemykin, P. Basu, Synthesis, Electrochemistry, Geometric and Electronic Structure of Oxo-Molybdenum Compounds Involved in an Oxygen Atom Transferring System. J. Inorg. Biochem. 102(4), 748-756 (2008)

25. A.B.P. -Lever, Inorganic spectroscopy, 2nd edn. (Elsevier, Amsterdam, 1984)

26. C.E. -Housecroft, A.G. Sharpe, Inorganic Chemistry, second ed., Pearson, England, 2005. p. 579

27. C. -Lee, W. Yang, G. Robert, Parr, Development of the Colle-Salvetti correlation-energy formula into a functional of the electron density. Physical review B 37(2), 785 (1988)

28. R. - Robinson Jr. et al., Sulfur Dioxide Activation: A Theoretical Investigation into Dual Sî» 0 Bond Cleavage by Three-Coordinate Molybdenum (III) Complexes. Inorganic chemistry 54(2), 534-543 (2015)

29. - Imane Seghir et al., DFT/TDDFT Investigation on the Electronic Structure and Spectroscopic Properties of Cis-Dioxomolybdenum (VI) Complexes, Acta Chim. Slov. 2019, 66, 629-637

30. - Stefan Peeters et al., Characterization of Molybdenum Dithiocarbamates by First-Principles Calculations, J. Phys. Chem. A 2019, 123, 7007-7015

31. R. - Robinson Jr., M.F. Shaw, R. Stranger, B.F. Yates, Theoretical study of the mechanism for the sequential $\mathrm{N}-\mathrm{O}$ and $\mathrm{N}-\mathrm{N}$ bond cleavage within $\mathrm{N} 2 \mathrm{O}$ adducts of $\mathrm{N}$-heterocyclic carbenes by vanadium(III) complex. Dalton Trans. 45, 1047-1054 (2016)

32. A.A. - Soliman et al., New formamidine ligands and their mixed ligand palladium(II) oxalate complexes: Synthesis, characterization, DFT calculations and in vitro cytotoxicity. Spectrochim. Acta Part A Mol. Biomol. Spectrosc. 152, 358-369 (2016)

33. A.A. - Soliman et al., "Soluble ruthenium (II) with 3, 4-diaminobenzoic acid complexes Preparation, thermal study, theoretical calculations and in vitro cytotoxic activity". J. Therm. Anal. Calorim. 135(4), 
2457-2473 (2019)

34. A.A. - Soliman, A.M. Sayed, O.I. Alajrawy, W. Linert, New palladium(II) formamidine complexes: preparation, characterization, theoretical calculations and cytotoxic activity. J. Mol. Struct. 5, 453460 (2017)

35. R.M.M. - Sara et al., Formation of Mono Oxo Molybdenum(IV) PNP Pincer Complexes: Interplay between Water and Molecular Oxygen, Eur. J. Inorg. Chem. 10.1002/ejic.201701413

36. S. - Raghvendra, N. Sengar, Victor, Nemykin, P. Basu, Synthesis, Electrochemistry, Geometric and Electronic Structure of Oxo-Molybdenum Compounds Involved in an Oxygen Atom Transferring System. J. Inorg. Biochem. 102(4), 748-756 (2008 April)

37. H.T. - Akcay, R. Bayrak, Computational studies on the anastrozole and letrozole, effective chemotherapy drugs against breast cancer. Spectrochim Acta A. 122, 142-152 (2014)

38. A.M. - Mansour, Coordination behavior of sulfamethazine drug towards $\mathrm{Ru}(\mathrm{III})$ and $\mathrm{Pt}(\mathrm{II})$ ions: Synthesis, spectral, DFT, magnetic, electrochemical and biological activity studies. Inorg. Chim. Acta 394, 436-445 (2013)

39. S.J. - Sabounchei, P. Shahriary, S. Salehzadeh, Y. Gholiee, D. Nematollahi, A. Chehregani, A. Amani, Z. Afsartala, $\mathrm{Pd}(\mathrm{II})$ and $\mathrm{Pd}(\mathrm{IV})$ complexes with 5-methyl-5-(4-pyridyl)hydantoin: Synthesis, physicochemical, theoretical, and pharmacological investigation. Spectrochim. Acta A. 135, 10191031 (2015)

40. M.L. -, B. Modzelewska-Banachiewicz, R. Paprocka, M. Zimecki, U.E. Wawrzyniak, J. Kutkowska, G. Ziółkowska, Synthesis, crystal structure and biological activities of a novel amidrazone derivative and its copper(II) complex -A potential antitumor drug. J. Inorg. Biochem. 114, 55-64 (2012)

41. - X. Assfeld, R. Jean-Louis, Quantum chemical computations on parts of large molecules: the ab initio local self consistent field method. Chemical physics letters 263(1-2), 100-106 (1996)

42. J. - Małecki, Grrzegorz, P. Zwoliński. "Synthesis, characterization and molecular structure of Pd (II) complex containing the methyl-hemiacetal form of isonicotinaldehyde." Polyhedron 39.1 (2012): 8590

43. - Štarha, Pavel, Igor Popa, and Zdeněk Trávníček. "Platinum (II) oxalato complexes involving adenosine-based n-donor ligands: Synthesis, characterization and cytotoxicity evaluation." Molecules 19.3 (2014): 3832-3847

44. P.K. - Chattaraj, A. Poddar, Molecular reactivity in the ground and excited electronic states through density-dependent local and global reactivity parameters. The Journal of Physical Chemistry A 103(43), 8691-8699 (1999)

\section{Tables}

Table 1 Some physical and analytical properties of the Mo(VI) and the Mo(IV) complexes 


\begin{tabular}{|c|c|c|c|c|c|c|c|}
\hline Complex & $\begin{array}{l}\text { Molar } \\
\text { mass }\end{array}$ & $\begin{array}{l}\text { Mass Spec. } \\
\mathrm{m} / \mathrm{z}\left(\mathrm{P}^{+}\right)\end{array}$ & m.p & color & $\begin{array}{l}\otimes_{\mathrm{m}} \mathrm{Ohm}^{-1} \\
\mathrm{~cm}^{2} \mathrm{~mol}^{-1}\end{array}$ & \multicolumn{2}{|c|}{$\begin{array}{l}\text { UV-Vis. absorption } \\
\text { peaks (nm) }\end{array}$} \\
\hline \multirow{4}{*}{$\begin{array}{l}{\left[\mathrm{MoO}_{2}(\mathrm{acac})\right.} \\
\text { (HPY)] }\end{array}$} & \multirow[t]{4}{*}{339.01} & \multirow[t]{4}{*}{338.4} & \multirow[t]{4}{*}{280} & \multirow[t]{4}{*}{ Brown } & 16.70 & 281 & \multirow{3}{*}{$\begin{array}{l}\text { Intra } \\
\text { ligand }\left(\pi \rightarrow \pi^{*}\right) \\
\text { Intra } \\
\text { ligand }\left(n \rightarrow \pi^{*}\right)\end{array}$} \\
\hline & & & & & \multirow[t]{3}{*}{ DMSO } & 325 & \\
\hline & & & & & & 407 & \\
\hline & & & & & & & LMCT \\
\hline \multirow{4}{*}{$\begin{array}{l}{\left[\mathrm{MoO}_{2}(\mathrm{DTO})\right.} \\
\text { (HPY)] }\end{array}$} & \multirow[t]{4}{*}{358.94} & \multirow[t]{4}{*}{356.6} & \multirow[t]{4}{*}{370} & \multirow{4}{*}{$\begin{array}{l}\text { Yellow } \\
\text { brown }\end{array}$} & 13.20 & 296 & \multirow{3}{*}{$\begin{array}{l}\text { Intra } \\
\text { ligand }\left(\pi \rightarrow \pi^{*}\right) \\
\text { Intra } \\
\text { ligand }\left(n \rightarrow \pi^{*}\right)\end{array}$} \\
\hline & & & & & \multirow{3}{*}{ DMSO } & 386 & \\
\hline & & & & & & 438 & \\
\hline & & & & & & & LMCT \\
\hline \multirow{5}{*}{$\begin{array}{l}{[\mathrm{MoO}(\mathrm{acac})} \\
(\mathrm{HPY})]\end{array}$} & \multirow[t]{5}{*}{323.02} & \multirow[t]{5}{*}{323.09} & \multirow[t]{5}{*}{240} & \multirow{5}{*}{$\begin{array}{l}\text { Dark } \\
\text { brown }\end{array}$} & 10.50 & 270 & \multirow{2}{*}{$\begin{array}{l}\text { Intra } \\
\text { ligand }\left(\pi \rightarrow \pi^{*}\right)\end{array}$} \\
\hline & & & & & \multirow[t]{4}{*}{ DMSO } & 318 & \\
\hline & & & & & & 440 & ligand $\left(n \rightarrow \pi^{*}\right)$ \\
\hline & & & & & & 637 & LMCT \\
\hline & & & & & & & $\begin{array}{l}\mathrm{d}-\mathrm{d} \\
\text { transitions }\end{array}$ \\
\hline \multirow{5}{*}{$\begin{array}{l}{[\mathrm{MoO}(\mathrm{DTO})} \\
\text { (HPY)] }\end{array}$} & \multirow[t]{5}{*}{342.95} & \multirow[t]{5}{*}{340.2} & \multirow[t]{5}{*}{$>300$} & \multirow{5}{*}{$\begin{array}{l}\text { Light } \\
\text { brown }\end{array}$} & 11.76 & 268 & \multirow{2}{*}{$\begin{array}{l}\text { Intra } \\
\text { ligand }\left(\pi \rightarrow \pi^{*}\right)\end{array}$} \\
\hline & & & & & \multirow[t]{4}{*}{ DMSO } & 369 & \\
\hline & & & & & & 447 & ligand $\left(n \rightarrow \pi^{*}\right)$ \\
\hline & & & & & & 704 & LMCT \\
\hline & & & & & & & $\begin{array}{l}\mathrm{d}-\mathrm{d} \\
\text { transitions }\end{array}$ \\
\hline
\end{tabular}

Table 2 The most diagnostic FT-IR bands experimental and calculated of the prepared complexes. 


\begin{tabular}{|c|c|c|c|}
\hline Compound & Exp. & Calc. & Assignment \\
\hline \multirow[t]{5}{*}{ 2-hydrazinopyridine } & 3395,3308 & 3444,3508 & $\mathrm{v}\left(\mathrm{NH}_{2}\right)$ \\
\hline & 1246 & 1299 & $\rho \mathrm{tNH}_{2}$ \\
\hline & 1086 & 1193 & $\rho \mathrm{wNH}_{2}$ \\
\hline & 804 & 866 & $\mathrm{prNH}_{2}$ \\
\hline & 3577 & 3607 & $\mathrm{U}(\mathrm{N}-\mathrm{H})$ \\
\hline \multirow[t]{5}{*}{ Dithiooximide } & 3291,3210 & 3482,3691 & $\mathrm{U}(\mathrm{N}-\mathrm{H})$ \\
\hline & 1196 & 1319 & $\rho \mathrm{tNH}_{2}$ \\
\hline & 1042 & 1232 & $\rho w \mathrm{wH}_{2}$ \\
\hline & 837 & 865 & $\mathrm{\rho rNH}_{2}$ \\
\hline & 1624 & 1632 & $\mathrm{u}(\mathrm{C}=\mathrm{N})$ \\
\hline \multirow[t]{7}{*}[\mathrm{MoO}_{2}(\mathrm{acac})(\mathrm{HPY})]{} & 3089,3016 & 3443,3553 & $\mathrm{v}\left(\mathrm{NH}_{2}\right)$ \\
\hline & 1519 & 1310 & $\rho \mathrm{tNH}_{2}$ \\
\hline & 1465 & 1179 & $\rho w N H_{2}$ \\
\hline & 1265 & 861 & $\mathrm{\rho rNH}_{2}$ \\
\hline & 3734 & 3639 & $\mathrm{u}(\mathrm{NH})$ \\
\hline & 1600 & 1612 & $\mathrm{u}(\mathrm{C}=0)$ \\
\hline & 883 & 979 & $\mathrm{O}=\mathrm{Mo}=\mathrm{O}$ \\
\hline \multirow[t]{7}{*}{$\left[\mathrm{MoO}_{2}(\mathrm{DTO})(\mathrm{HPY})\right]$} & 3618,3047 & 3445,3577 & $\mathrm{u}\left(\mathrm{NH}_{2}\right)$ \\
\hline & 1527 & 1307 & $\rho \mathrm{tNH}_{2}$ \\
\hline & 1388 & 1165 & $\rho w \mathrm{NH}_{2}$ \\
\hline & 1107 & 888 & $\mathrm{prNH}_{2}$ \\
\hline & 3618 & 3631 & $\mathrm{u}(\mathrm{NH})$ \\
\hline & 1697 & 1618 & $\mathrm{u}(\mathrm{C}=\mathrm{N})$ \\
\hline & 921,1110 & 960,1190 & $\mathrm{O}=\mathrm{Mo}=0$ \\
\hline \multirow[t]{2}{*}[\mathrm{MoO}(\mathrm{acac})(\mathrm{HPY})]{} & 3606,3101 & 3409,3508 & $\mathrm{u}\left(\mathrm{NH}_{2}\right)$ \\
\hline & 1415 & 1285 & $\rho \mathrm{tNH}_{2}$ \\
\hline
\end{tabular}




\begin{tabular}{|c|c|c|c|}
\hline & 1319 & 1189 & $\mathrm{pwNH}_{2}$ \\
\hline & 1269 & 769 & $\mathrm{prNH}_{2}$ \\
\hline & 3838 & 3643 & $\mathrm{U}(\mathrm{N}-\mathrm{H})$ \\
\hline & 1519 & 1585 & $\mathrm{u}(\mathrm{C}=\mathrm{O})$ \\
\hline & 952 & 1017 & $M o=0$ \\
\hline \multirow[t]{7}{*}{ [MoO(DTO)(HPY)] } & 3738,3603 & 3402,3513 & $\mathrm{u}\left(\mathrm{NH}_{2}\right)$ \\
\hline & 1523 & 1279 & $\rho \mathrm{NH}_{2}$ \\
\hline & 1122 & 1171 & $\mathrm{pwNH}_{2}$ \\
\hline & 705 & 858 & $\mathrm{prNH}_{2}$ \\
\hline & 3857 & 3649 & $\mathrm{u}(\mathrm{NH})$ \\
\hline & 1670 & 1599 & $\mathrm{U}(\mathrm{C}=\mathrm{N})$ \\
\hline & 952 & 996 & $M o=0$ \\
\hline
\end{tabular}

Table 3 Mass fragments data of the prepared complexes.

\begin{tabular}{|c|c|c|c|}
\hline Complex & $\begin{array}{l}\text { Molar } \\
\text { mass }\end{array}$ & $\begin{array}{l}\text { Mass } \\
\text { spec. } \\
\mathrm{m} / \mathrm{z} \\
\left(\mathrm{P}^{+}\right)\end{array}$ & $(\mathrm{m} / \mathrm{z})$ values \\
\hline $\begin{array}{l}{\left[\mathrm{MoO}_{2}(\mathrm{acac})\right.} \\
(\mathrm{HPY})]\end{array}$ & 339.01 & 338.4 & $\begin{array}{l}\text { 338.4(M), 238.28(M-acac),230.94(M-HPY), } 130.16\left(\mathrm{MoO}_{2}\right) \text {, } \\
95.08,96.0 \text { and } 96.79(\mathrm{Mo}) \text { isotopes }\end{array}$ \\
\hline $\begin{array}{l}{\left[\mathrm{MoO}_{2}(\mathrm{DTO})\right.} \\
(\mathrm{HPY})]\end{array}$ & 358.94 & 356.6 & $\begin{array}{l}356.66 \text { (M), 250.40(M-HPY), 235.59(M-DTO), } 129.26\left(\mathrm{MoO}_{2}\right) \\
119.89 \text { (DTO), } 110.76 \text { (HPY) ligand, } 97.41,98.86101 .37 \text { (Mo) } \\
\text { isotopes. }\end{array}$ \\
\hline $\begin{array}{l}{[\mathrm{MoO}(\mathrm{acac})} \\
(\mathrm{HPY})]\end{array}$ & 323.02 & 323.09 & $\begin{array}{l}323.09 \text { (M), } 215.01 \text { (M-HPY), 227. } 14 \text { (M-acac), } 115.64 \\
\text { (MoO), 108.24 (HPY) ligand, } 97.41,98.86 \text { and 101.37 (Mo) } \\
\text { isotopes }\end{array}$ \\
\hline $\begin{array}{l}{[\mathrm{MoO}(\mathrm{DTO})} \\
\text { (HPY)] }\end{array}$ & 342.95 & 340.2 & $\begin{array}{l}\text { 340.2(M), 225.93(M-DTO), 235.15(M-HPY), 113.26(HPY), } \\
121.19 \text { (DTO), } 111.96 \text { (HPY), } 99.05 \text { molybdenum isotope }\end{array}$ \\
\hline
\end{tabular}

Table 4: The experimental and calculated ${ }^{1} \mathrm{H}$-NMR data of the 2-hydrazinopyridine (HPY), dithiooximide ligands and the molybdenum ( $\mathrm{VI})$ complexes measured in a DMSO-d $\mathrm{d}^{6}$ as a solvent and DFT/6-31G (d, P) and LanL2DZ basis sets. 


\begin{tabular}{|c|c|c|c|}
\hline Compound & Exp. & Calc. & Assignment \\
\hline \multirow[b]{2}{*}{ 2-hydrazinopyridine (HPY) } & $4.36(4 \mathrm{H})$ & $2.05-2.69$ & $\mathrm{NH}_{2}$ protons \\
\hline & $6.382-6.50(4 \mathrm{H})$ & $6.20-6.45$ & pyridine group protons \\
\hline \multirow[t]{3}{*}{ Dithiooximide } & 1.89 & - & SH proton \\
\hline & $6.51-9.6(8 \mathrm{H})$ & $6.95-9.19$ & $\mathrm{NH} 2$ \\
\hline & $10.16(\mathrm{H})$ & - & $\mathrm{NH}$ proton \\
\hline \multirow[t]{5}{*}[\mathrm{MoO}_{2}(\mathrm{acac})(\mathrm{HPY})]{} & $3.36-3.45$ & $4.42-4.50(2 \mathrm{H})$ & $\mathrm{NH}_{2}$ protons \\
\hline & $1.07-2.22$ & $1.32-1.96$ & $\mathrm{CH}_{3}$ (acac) \\
\hline & 2.65 & $2.96(1 \mathrm{H})$ & $\mathrm{NH}$ \\
\hline & $6.84-8.08$ & $6.24-8.02(4 \mathrm{H})$ & pyridine group protons \\
\hline & 6.11 & $6.05(1 \mathrm{H})$ & $\mathrm{CH}$-acac \\
\hline \multirow[t]{4}{*}[\mathrm{MoO}_{2}(\mathrm{DTO})(\mathrm{HPY})]{} & $4.21-4.30$ & $4.16(\mathrm{H})$ & $\mathrm{NH}-\mathrm{HPY}$ \\
\hline & 2.23-3.37 & $3.91-4.41(2 \mathrm{H})$ & $\mathrm{NH}_{2}-\mathrm{HPY}$ \\
\hline & $7.15-8.46$ & $5.74-8.08 \quad(4 \mathrm{H})$ & pyridine group protons \\
\hline & $9.69-10.21$ & $9.90-10.35(2 \mathrm{H})$ & NH-DTO \\
\hline
\end{tabular}

$s=$ single, $m=$ multiple

Table 5 The bond lengths and bond angles of the $\mathrm{Mo}(\mathrm{VI})$ and the Mo(IV) complexes using the DFT/B3LYP/Lan2DZ basis set. 


\begin{tabular}{|c|c|c|c|}
\hline$\left[\mathrm{MoO}_{2}(\mathrm{acac})(\mathrm{HPY})\right]$ & Bond Lengths ${ }^{\circ} \mathrm{A}$ & & Bond Angles $^{\circ}$ \\
\hline $\mathrm{Mo}(1)-\mathrm{N}(17)$ & 2.41 & $\mathrm{~N}(16)-\mathrm{Mo}(1)-\mathrm{N}(17)$ & 72.58 \\
\hline Mo(1)-N(16) py & 2.18 & $\mathrm{O}(9)=\mathrm{Mo}(1)=\mathrm{O}(10)$ & 106.74 \\
\hline $\mathrm{Mo}(1)=\mathrm{O}(9)$ & 1.72 & $\mathrm{O}(4)-\mathrm{Mo}(1)-\mathrm{O}(7)$ acac & 78.38 \\
\hline $\mathrm{Mo}(1)=\mathrm{O}(10)$ & 1.72 & $\mathrm{O}(10)=\mathrm{Mo}(1)-\mathrm{O}(4)$ & 98.95 \\
\hline $\mathrm{Mo}(1)-\mathrm{O}(7)$ & 2.19 & $\mathrm{~N}(16)-\mathrm{Mo}(1)=\mathrm{O}(10)$ & 95.83 \\
\hline $\mathrm{Mo}(1)-\mathrm{O}(16)$ & 1.98 & $\mathrm{O}(7)-\mathrm{Mo}(1)-\mathrm{N}(16)$ & 81.33 \\
\hline \multicolumn{4}{|l|}{$\left[\mathrm{MoO}_{2}(\mathrm{DTO})(\mathrm{HPY})\right]$} \\
\hline $\mathrm{Mo}(1)-\mathrm{N}(8)$ py & 2.20 & $\mathrm{~N}(8)-\mathrm{Mo}(1)-\mathrm{N}(9)$ & 71.51 \\
\hline $\mathrm{Mo}(1)-\mathrm{N}(9)$ & 2.44 & $\mathrm{O}(2)=\mathrm{Mo}(1)=\mathrm{O}(17)$ & 107.51 \\
\hline $\mathrm{Mo}(1)=\mathrm{O}(2)$ & 1.73 & $S(15)-M o(1)-S(16)$ & 81.49 \\
\hline $\mathrm{Mo}(1)=\mathrm{O}(17)$ & 1.75 & $\mathrm{~S}(16)-\mathrm{Mo}(1)-\mathrm{O}(17)$ & 92.41 \\
\hline Mo(1)-S(15) & 2.65 & $\mathrm{O}(17)-\mathrm{Mo}(1)-\mathrm{N}(8)$ & 100.47 \\
\hline $\mathrm{Mo}(1)-\mathrm{S}(16)$ & 2.45 & $\mathrm{~S}(16)-\mathrm{Mo}(1)-\mathrm{N}(9)$ & 89.55 \\
\hline \multicolumn{4}{|l|}{ [MoO(acac)(HPY)] } \\
\hline $\mathrm{Mo}(1)-\mathrm{N}(16)$ & 2.21 & $\mathrm{~N}(15)-\mathrm{Mo}(1)-\mathrm{N}(16)$ & 77.18 \\
\hline Mo(1)-N(15) py & 2.12 & $\mathrm{O}(4)-\mathrm{Mo}(1)-\mathrm{O}(7)$ & 83.31 \\
\hline $\mathrm{Mo}(1)-\mathrm{O}(4)$ & 2.06 & $\mathrm{~N}(15)-\mathrm{Mo}(1)-\mathrm{O}(7)$ & 90.39 \\
\hline $\mathrm{Mo}(1)-\mathrm{O}(7)$ & 2.07 & $\mathrm{~N}(16)-\mathrm{Mo}(1)-\mathrm{O}(4)$ & 80.10 \\
\hline \multirow[t]{2}{*}{$\mathrm{Mo}(1)=\mathrm{O}(9)$} & 1.70 & $\mathrm{~N}(15)-\mathrm{Mo}(1)=\mathrm{O}(9)$ & 110.42 \\
\hline & & $\mathrm{O}(7)-\mathrm{Mo}(1)=\mathrm{O}(9)$ & 106.20 \\
\hline \multicolumn{4}{|l|}{ [MoO(DTO)(HPY)] } \\
\hline $\mathrm{Mo}(1)-\mathrm{N}(8)$ py & 2.18 & $\mathrm{~N}(8)-\mathrm{Mo}(1)-\mathrm{N}(9)$ & 74.85 \\
\hline $\mathrm{Mo}(1)-\mathrm{N}(9)$ & 2.24 & $\mathrm{~S}(15)-\mathrm{Mo}(1)-\mathrm{S}(16)$ & 85.30 \\
\hline $\mathrm{Mo}(1)-\mathrm{S}(15)$ & 2.42 & $\mathrm{~S}(16)-\mathrm{Mo}(1)-\mathrm{N}(9)$ & 81.65 \\
\hline $\mathrm{Mo}(1)-\mathrm{S}(16)$ & 2.44 & $\mathrm{~S}(15)-\mathrm{Mo}(1)-\mathrm{N}(8)$ & 87.79 \\
\hline \multirow[t]{2}{*}{$\mathrm{Mo}(1)=\mathrm{O}(2)$} & 1.71 & $\mathrm{~S}(15)-\mathrm{Mo}(1)-\mathrm{O}(2)$ & 110.61 \\
\hline & & $\mathrm{N}(8)-\mathrm{Mo}(1)-\mathrm{O}(2)$ & 110.24 \\
\hline
\end{tabular}


Table 6 The calculated quantum chemical parameters of the 2-hydrazinopyridine (HPY), dithiooxamide, acetylacetone ligands the Mo(VI) and the Mo(IV) complexes by DFT/B3LYP/6-31G(d, P) for the (HPY) ligand and LanL2DZ for the complexes basis sets.

\begin{tabular}{|lllllll|}
\hline Compound & HOMO & LUMO & $\eta$ & $\Delta \mathrm{E}$ & Electronic & D.M \\
& a.u & a.u & & a.u & Energy a.u & Debye \\
\hline 2-hydrazinopyridine & -0.216 & 0.025 & 0.095 & 0.191 & -359.06 & 1.46 \\
\hline Dithiooxiamaid & -0.262 & -0.081 & 0.090 & 0.181 & -984.54 & 1.67 \\
\hline$\left[\mathrm{MoO}_{2}(\mathrm{acac})(\mathrm{HPY})\right]$ & -0.229 & -0.124 & 0.052 & 0.105 & -784.07 & 10.80 \\
\hline$\left[\mathrm{MoO}_{2}(\mathrm{DTO})(\mathrm{HPY})\right]$ & -0.377 & -0.247 & 0.065 & 0.130 & -921.99 & 8.11 \\
\hline$[\mathrm{MoO}(\mathrm{acac})(\mathrm{HPY})]$ & -0.192 & -0.093 & 0.045 & 0.099 & -708.85 & 13.72 \\
\hline$[\mathrm{MoO}(\mathrm{DTO})(\mathrm{HPY})]$ & -0.318 & -0.208 & 0.055 & 0.110 & -846.76 & 6.63 \\
\hline
\end{tabular}

Table 7 The excitation energies $(\mathrm{eV})$, electronic transition configurations and oscillator strengths $(f)$ of the $\mathrm{Mo}(\mathrm{VI})$ and $\mathrm{Mo}(\mathrm{IV})$ complexes. 


\begin{tabular}{|c|c|c|c|c|}
\hline Complex & $\begin{array}{l}\text { Calc. } \\
\mathrm{nm}\left(\mathrm{cm}^{-1}\right)\end{array}$ & $\begin{array}{l}\text { Exp. } \\
\mathrm{nm}\end{array}$ & $f$ & Composition (>20\%) \\
\hline \multirow[t]{4}{*}{$\begin{array}{l}{\left[\mathrm{MoO}_{2}(\mathrm{acac})\right.} \\
(\mathrm{HPY})]\end{array}$} & 260(38414) & 281 & 0.063 & $\begin{array}{l}\text { HOMO } \rightarrow \text { LUMO+4(42\%), HOMO-6 } \rightarrow \text { LUMO+1(28\%), } \\
\text { HOMO- } 1 \rightarrow \text { LUMO+1(24\%) }\end{array}$ \\
\hline & $370(26961)$ & 325 & 0.011 & HOMO-1 $\rightarrow$ LUMO+1(65\%) \\
\hline & $400(24971)$ & 407 & 0.013 & HOMO-1 $\rightarrow$ LUMO(65\%), HOMO-1 $\rightarrow$ LUMO+1(21\%) \\
\hline & $446(22396)$ & 430 & 0.002 & HOMO $\rightarrow$ LUMO(70\%) \\
\hline \multirow{6}{*}{$\begin{array}{l}{\left[\left[\mathrm{MoO}_{2}(\mathrm{DTO})\right.\right.} \\
(\mathrm{HPY})]\end{array}$} & \multirow{2}{*}{$\begin{array}{l}284 \\
(35134)\end{array}$} & \multirow[t]{2}{*}{296} & \multirow[t]{2}{*}{0.94} & HOMO-3 $\rightarrow$ LUMO+3(30\%), HOMO $\rightarrow$ LUMO $+5(24 \%)$ \\
\hline & & & & HOMO-5 $\rightarrow$ LUMO+1(23\%), HOMO-3 $\rightarrow$ LUMO+2(20\%) \\
\hline & \multirow[t]{2}{*}{$371(26923)$} & \multirow[t]{2}{*}{368} & \multirow[t]{2}{*}{0.013} & HOMO-7 $\rightarrow$ LUMO(45\%), HOMO-4 $\rightarrow$ LUMO(42\%) \\
\hline & & & & HOMO-3 $\rightarrow$ LUMO+1(22\%) \\
\hline & $440(22692)$ & 438 & 0.008 & HOMO-1 $\rightarrow$ LUMO+1(60\%), HOMO-3 $\rightarrow$ LUMO+1(24\%) \\
\hline & $541(18472)$ & 470 & 0.007 & HOMO-1 $\rightarrow$ LUMO(64\%), HOMO-2 $\rightarrow$ LUMO(22\%) \\
\hline \multirow{4}{*}{$\begin{array}{l}{[\mathrm{MoO}(\mathrm{acac})} \\
(\mathrm{HPY})]\end{array}$} & 280(35689) & 270 & 0.058 & HOMO-2 $\rightarrow$ LUMO+1(67\%) \\
\hline & $315(31714)$ & 318 & 0.043 & HOMO-1 $\rightarrow$ LUMO(66\%) \\
\hline & $377(26511)$ & 440 & 0.016 & $\mathrm{HOMO} \rightarrow \mathrm{LUMO}+3(44 \%), \mathrm{HOMO} \rightarrow \mathrm{LUMO}+5(40 \%)$ \\
\hline & $508(19669)$ & 637 & 0.010 & $\mathrm{HOMO} \rightarrow \mathrm{LUMO}+2(57 \%), \mathrm{HOMO} \rightarrow \mathrm{LUMO}+1(27 \%)$ \\
\hline \multirow{4}{*}{$\begin{array}{l}{[[\mathrm{MoO}(\mathrm{DTO})} \\
(\mathrm{HPY})]\end{array}$} & 272(36668) & 268 & 0.035 & HOMO-7 $\rightarrow$ LUMO(49\%), HOMO-1 $\rightarrow$ LUMO+5(28\%) \\
\hline & $379(26353)$ & 269 & 0.013 & HOMO-2 $\rightarrow$ LUMO(64\%) \\
\hline & $460(21700)$ & 447 & 0.009 & $\mathrm{HOMO} \rightarrow \mathrm{LUMO}+4(46 \%), \mathrm{HOMO} \rightarrow \mathrm{LUMO}+2(36 \%)$ \\
\hline & $661(15123)$ & 704 & 0.023 & HOMO $\rightarrow$ LUMO(61\%) \\
\hline
\end{tabular}

Table 8 Excitation energies (a.u), \% contribution from molybdenum, 2-hydrazinopyridine, acetylacetone, dithiooximide ligands and the main character of some frontier orbitals of the studied complexes. 


\begin{tabular}{|c|c|c|c|c|c|c|}
\hline Complex & Orbital & $\begin{array}{l}\text { Energy } \\
\text { (a.u.) }\end{array}$ & HPY & Mo & acac & Main character \\
\hline $\begin{array}{l}{\left[\mathrm{MoO}_{2}(\mathrm{acac})(\mathrm{HPY})\right]} \\
(70)\end{array}$ & HOMO & -0.377 & $99 \%$ & $0 \%$ & $0 \%$ & $\operatorname{HPY}(\pi)$ \\
\hline (69) & HOMO-1 & -0.393 & $3 \%$ & $1 \%$ & $91 \%$ & $\operatorname{acac}(\pi)$ \\
\hline (68) & HOMO-2 & -0.416 & $3 \%$ & $3 \%$ & $86 \%$ & $\operatorname{acac}(\pi)$ \\
\hline (67) & HOMO-3 & -0.431 & $10 \%$ & $4 \%$ & $3 \%$ & $\mathrm{O}_{2}(\pi)$ \\
\hline$(66)$ & HOMO-4 & -0.441 & $76 \%$ & $2 \%$ & $7 \%$ & HPY(Py) \\
\hline (71) & LUMO & -0.247 & $13 \%$ & $52 \%$ & $17 \%$ & $M o(d x z, d x y)$ \\
\hline (72) & LUMO+1 & -0.126 & $9 \%$ & $51 \%$ & $15 \%$ & Mo(dxy) \\
\hline (73) & LUMO+2 & -0.211 & $6 \%$ & $54 \%$ & $18 \%$ & Mo(dyz) \\
\hline (74) & LUMO+3 & -0.205 & $7 \%$ & $19 \%$ & $69 \%$ & $\operatorname{acac}\left(\pi^{\star}\right)$ \\
\hline \multirow[t]{2}{*}{ (75) } & LUMO+4 & -0.005 & $90 \%$ & $7 \%$ & $1 \%$ & $\operatorname{HPY}\left(\pi^{\star}\right)$ \\
\hline & & & HPY & Mo & DTO & \\
\hline $\begin{array}{l}{\left[\mathrm{MoO}_{2}(\mathrm{DTO})(\mathrm{HPY})\right]} \\
(64)\end{array}$ & HOMO & -0.229 & $1 \%$ & $1 \%$ & $89 \%$ & DTO(ח) \\
\hline (63) & HOMO-1 & -0.244 & $3 \%$ & $7 \%$ & $78 \%$ & DTO(ח) \\
\hline (62) & HOMO-2 & -0.247 & $2 \%$ & $1 \%$ & $94 \%$ & DTO(ח) \\
\hline (61) & HOMO-3 & -0.261 & $14 \%$ & $12 \%$ & $64 \%$ & DTO(ח) \\
\hline$(60)$ & HOMO-4 & -0.277 & $94 \%$ & $1 \%$ & $3 \%$ & $\operatorname{HPY}(\pi)$ \\
\hline (65) & LUMO & -0.124 & $18 \%$ & $50 \%$ & $11 \%$ & Mo(dxy) \\
\hline (66) & LUMO+1 & -0.107 & $18 \%$ & $54 \%$ & $8 \%$ & $\mathrm{Mo}(\mathrm{dxz})$ \\
\hline (67) & LUMO+2 & -0.084 & $48 \%$ & $28 \%$ & $14 \%$ & $\begin{array}{l}\operatorname{HPY}\left(\pi^{\star}\right), \mathrm{Mo}(\mathrm{dxz}, \\
\mathrm{dyz})\end{array}$ \\
\hline (68) & LUMO+3 & -0.081 & $48 \%$ & $32 \%$ & $10 \%$ & $\begin{array}{l}\operatorname{HPY}\left(\pi^{\star}\right), M o\left(d x^{2}-\right. \\
\left.y^{2}, d y z\right)\end{array}$ \\
\hline \multirow[t]{2}{*}{ (69) } & LUMO+4 & -0.055 & $26 \%$ & $10 \%$ & $60 \%$ & $\operatorname{DTO}\left(\pi^{\star}\right)$ \\
\hline & & & HPY & Mo & acac & \\
\hline $\begin{array}{l}{[\mathrm{MoO}(\mathrm{acac})(\mathrm{HPY})]} \\
(66)\end{array}$ & HOMO & -0.138 & $14 \%$ & $74 \%$ & $12 \%$ & $\operatorname{Mo}\left(d x^{2}-y^{2}, d x y\right)$ \\
\hline (65) & HOMO-1 & -0.377 & $19 \%$ & $1 \%$ & $77 \%$ & $\operatorname{acac}(\pi)$ \\
\hline
\end{tabular}




\begin{tabular}{|c|c|c|c|c|c|c|}
\hline (64) & HOMO-2 & -0.380 & $83 \%$ & $1 \%$ & $15 \%$ & $\operatorname{HPY}(\pi)$ \\
\hline (63) & HOMO-3 & -0.411 & $4 \%$ & $5 \%$ & $85 \%$ & $\operatorname{acac}(\pi)$ \\
\hline$(62)$ & HOMO-4 & -0.439 & $17 \%$ & $6 \%$ & $52 \%$ & $\operatorname{acac}(\pi)$ \\
\hline (67) & LUMO & -0.439 & $31 \%$ & $20 \%$ & $42 \%$ & $\operatorname{acac}\left(\pi^{*}\right), \operatorname{HPY}\left(\pi^{*}\right)$ \\
\hline$(68)$ & LUMO+1 & -0.197 & $51 \%$ & $12 \%$ & $32 \%$ & $\begin{array}{l}\operatorname{HPY}\left(\pi^{*}\right) \\
\operatorname{acac}\left(\pi^{*}\right)\end{array}$ \\
\hline (69) & LUMO+2 & -0.171 & $13 \%$ & $46 \%$ & $28 \%$ & $M o(d y z, d x z)$ \\
\hline (70) & LUMO+3 & -0.155 & $87 \%$ & $9 \%$ & $2 \%$ & $\operatorname{HPY}\left(\pi^{\star}\right)$ \\
\hline \multirow[t]{2}{*}{ (71) } & LUMO+4 & -0.144 & $32 \%$ & $49 \%$ & $9 \%$ & $\operatorname{HPY}\left(\pi^{\star}\right)$ \\
\hline & & & HPY & Mo & DTO & \\
\hline $\begin{array}{l}{[[\mathrm{MoO}(\mathrm{DTO})(\mathrm{HPY})]} \\
(60)\end{array}$ & HOMO & -0.192 & $12 \%$ & $65 \%$ & $24 \%$ & $\operatorname{Mo}\left(d x^{2}-y^{2}, d x y\right)$ \\
\hline (59) & HOMO-1 & -0.217 & $5 \%$ & $4 \%$ & $86 \%$ & DTO(ח) \\
\hline (58) & HOMO-2 & -0.235 & $5 \%$ & $6 \%$ & $82 \%$ & DTO(п) \\
\hline (57) & HOMO-3 & -0.244 & $3 \%$ & $11 \%$ & $85 \%$ & DTO(ח) \\
\hline (56) & HOMO-4 & -0.250 & $3 \%$ & $18 \%$ & $76 \%$ & DTO(ח) \\
\hline (61) & LUMO & -0.039 & $89 \%$ & $6 \%$ & $2 \%$ & $\operatorname{HPY}\left(\pi^{\star}\right)$ \\
\hline (62) & LUMO+1 & -0.056 & $95 \%$ & $2 \%$ & $2 \%$ & $\operatorname{HPY}\left(\pi^{\star}\right)$ \\
\hline (63) & LUMO+2 & -0.051 & $3 \%$ & $12 \%$ & $82 \%$ & $\operatorname{DTO}\left(\pi^{*}\right)$ \\
\hline (64) & LUMO+3 & -0.041 & $21 \%$ & $56 \%$ & $8 \%$ & Mo(dyz, dxz) \\
\hline (65) & LUMO+4 & -0.033 & $33 \%$ & $46 \%$ & $9 \%$ & $\mathrm{Mo}(\mathrm{dxz}, \mathrm{dyz})$ \\
\hline
\end{tabular}

\section{Figures}




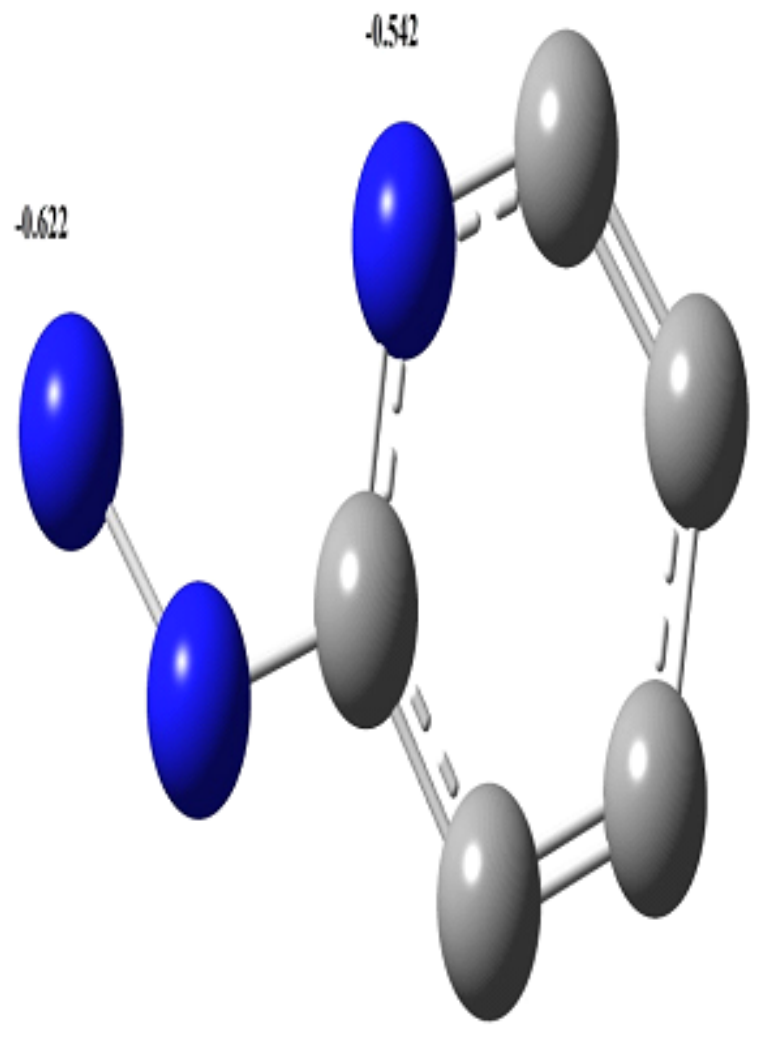

2-Hydrazinopyri dine (HPY)

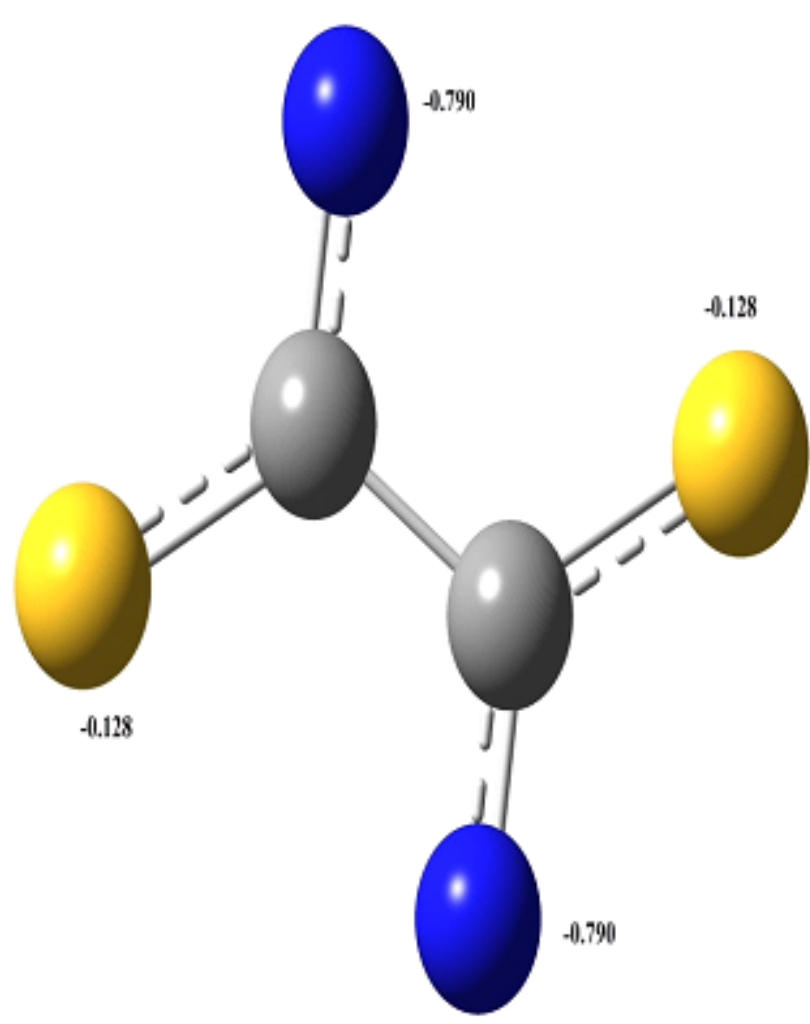

Dithiooximide (DTO)

Figure 1

The structures and NBO charges of the ligands. 

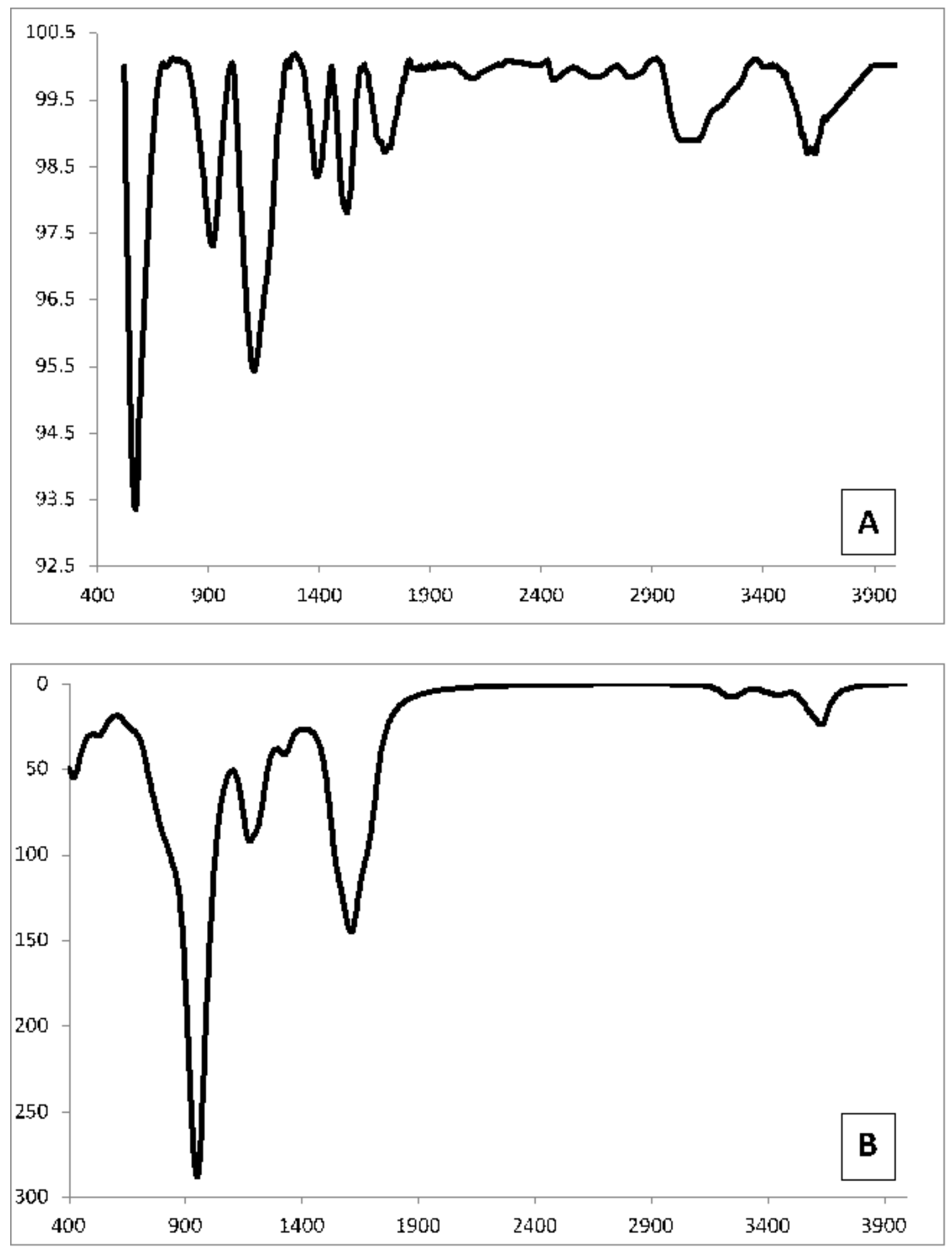

Figure 2

The experimental (a) and calculated (b) FT-IR spectrum of the [MoO2(DTO)(HPY)] complex. 


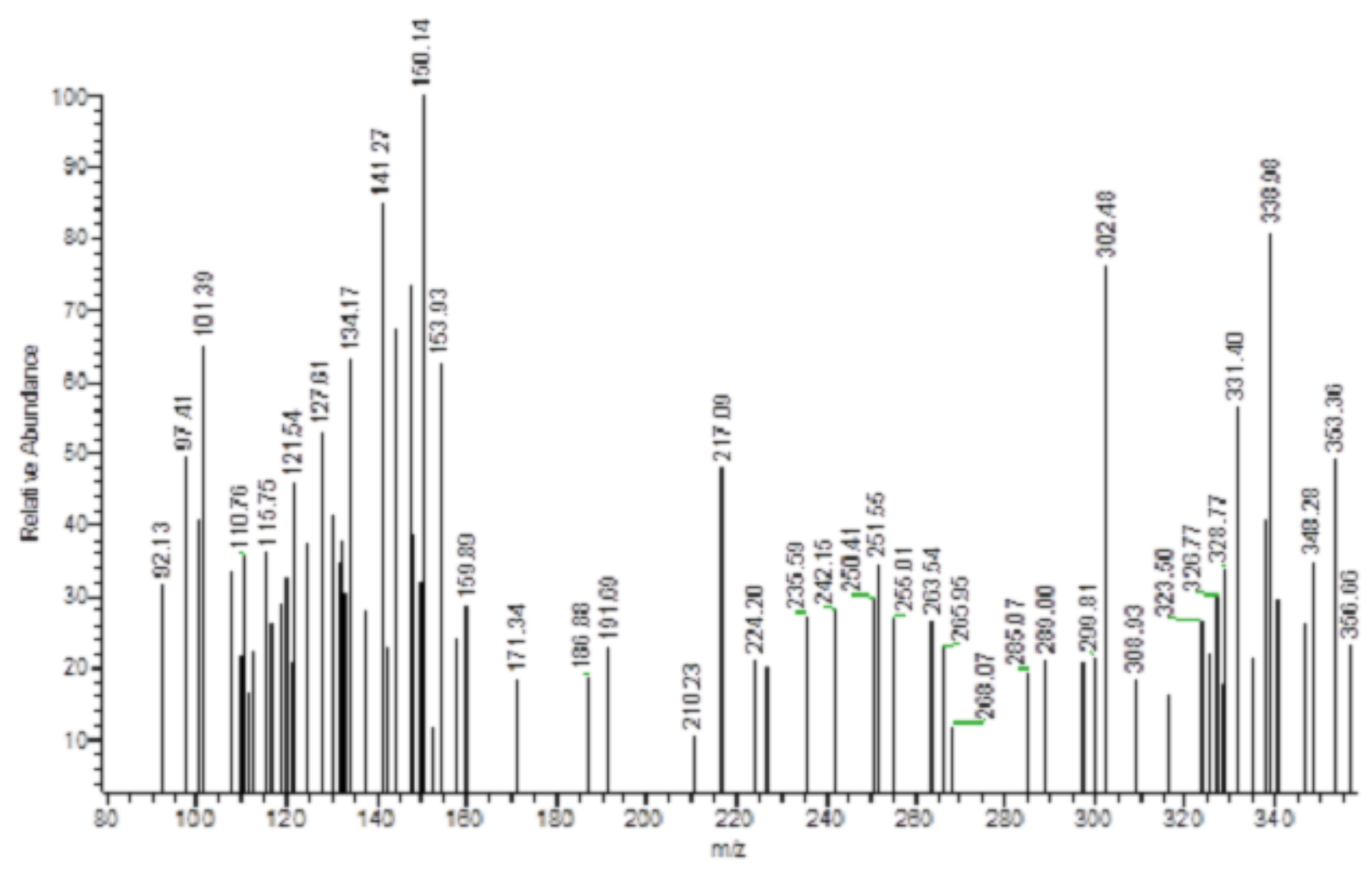

Figure 3

Mass spectrum of the [MoO2(DTO)(HPY)] complex.

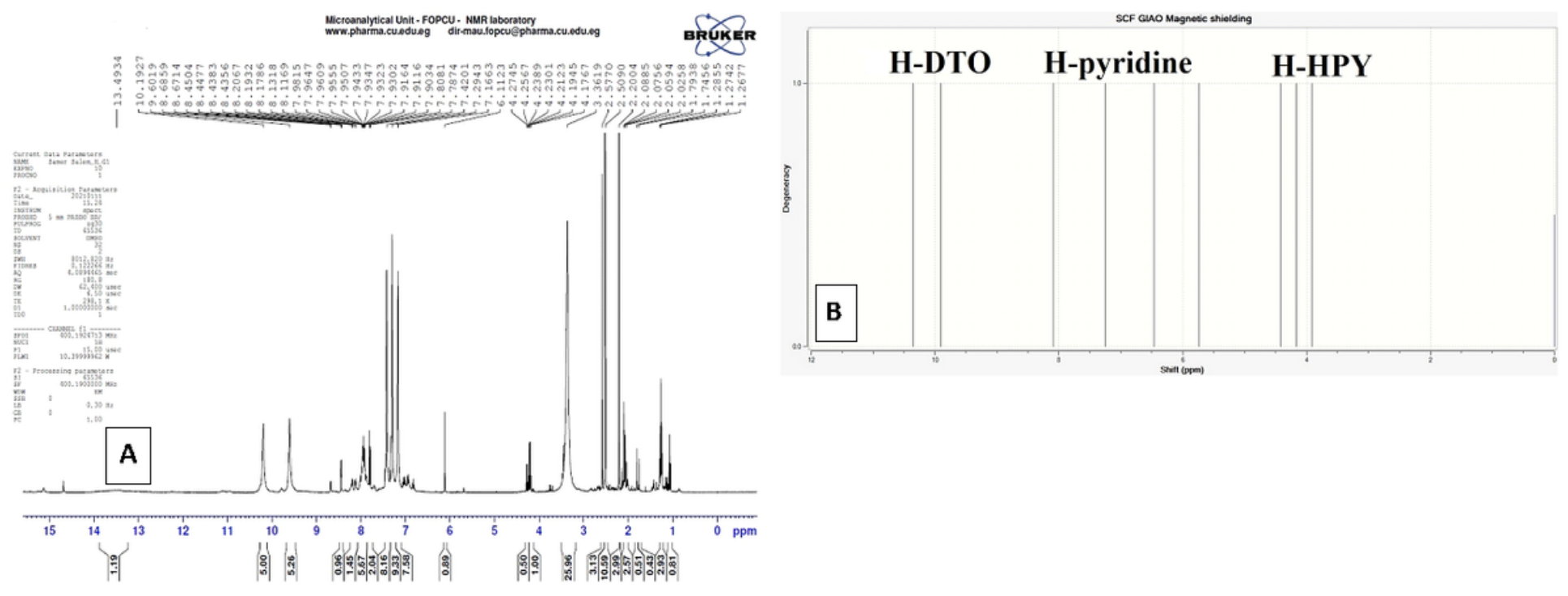

Figure 4

The experimental (a) and calculated (b) 1H-NMR spectra of the [MoO2(DTO)(HPY)] complex. 

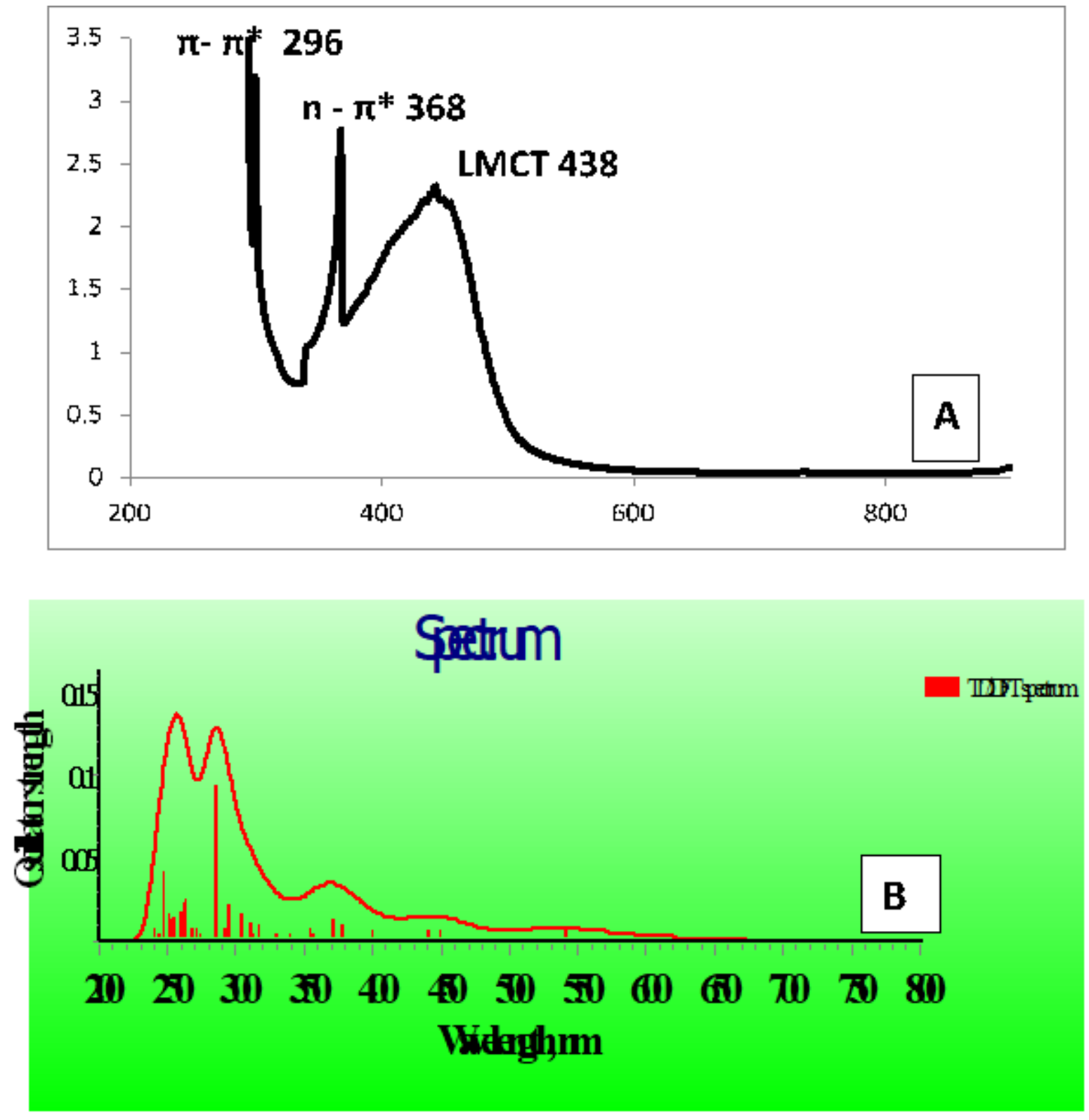

Figure 5

The experimental (a) and calculated (b) UV-Vis. spectra of the [MoO2(DTO)(HPY)] complex. 


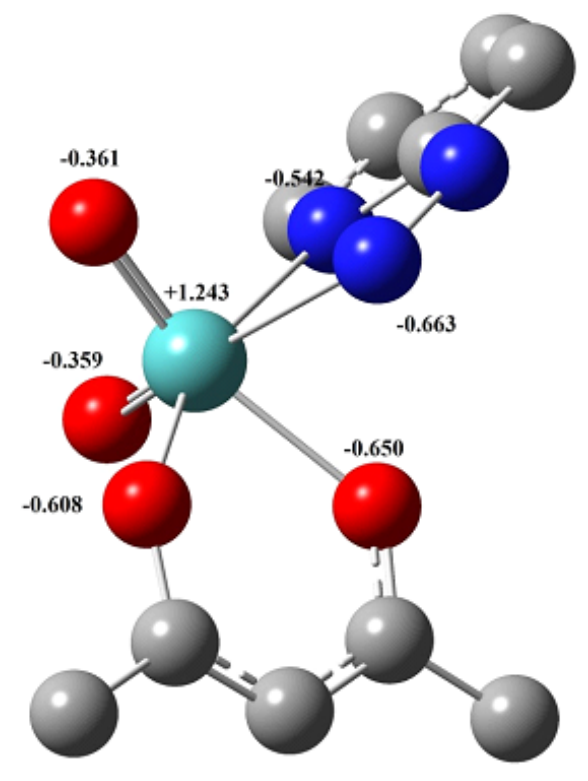

$\left[\mathrm{MoO}_{2}(\mathrm{acac})(\mathrm{HPY})\right]$ complex

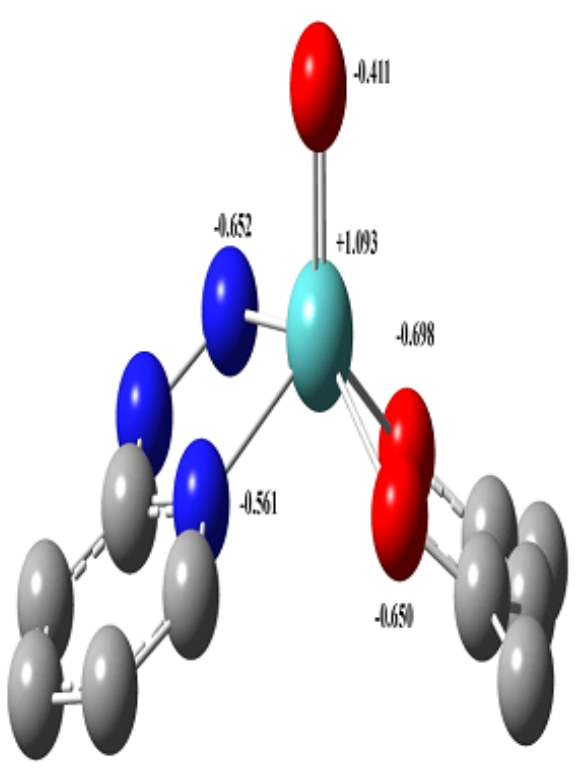

[MoO(acac)(HPY)] complex

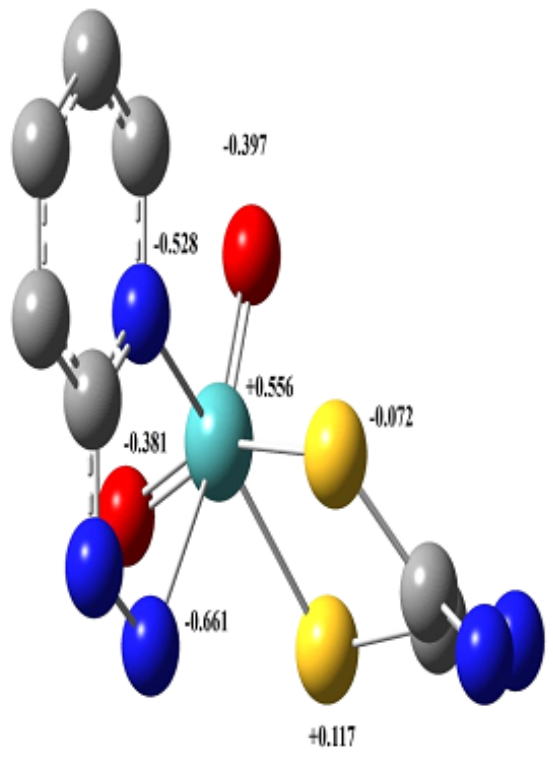

$\left[\mathrm{MoO}_{2}(\mathrm{DT} \mathrm{O})(\mathrm{HPY})\right]$ complex

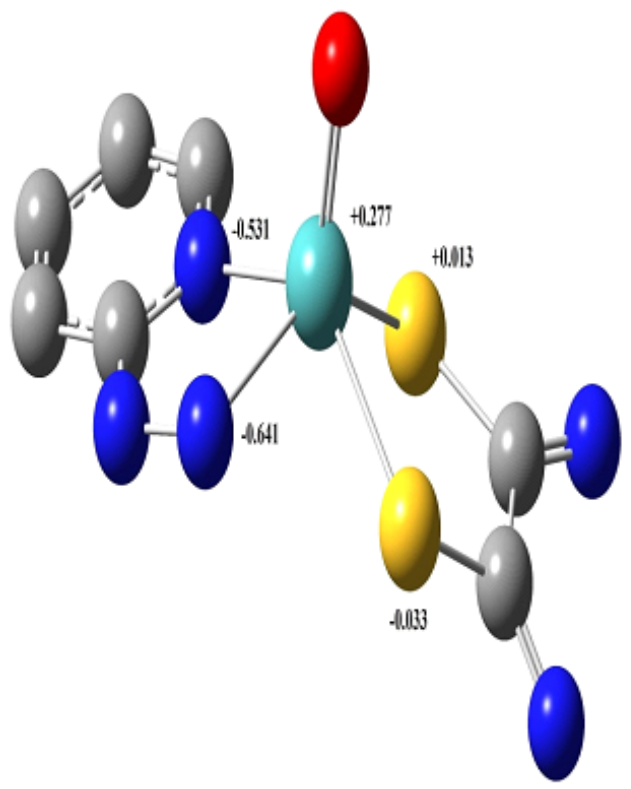

[MoO(DT O)(HPY)] complex

\section{Figure 6}

The proposed structures and NBO charges of the dioxomolybdenum(VI) and oxomolybdenum(IV) complexes. 

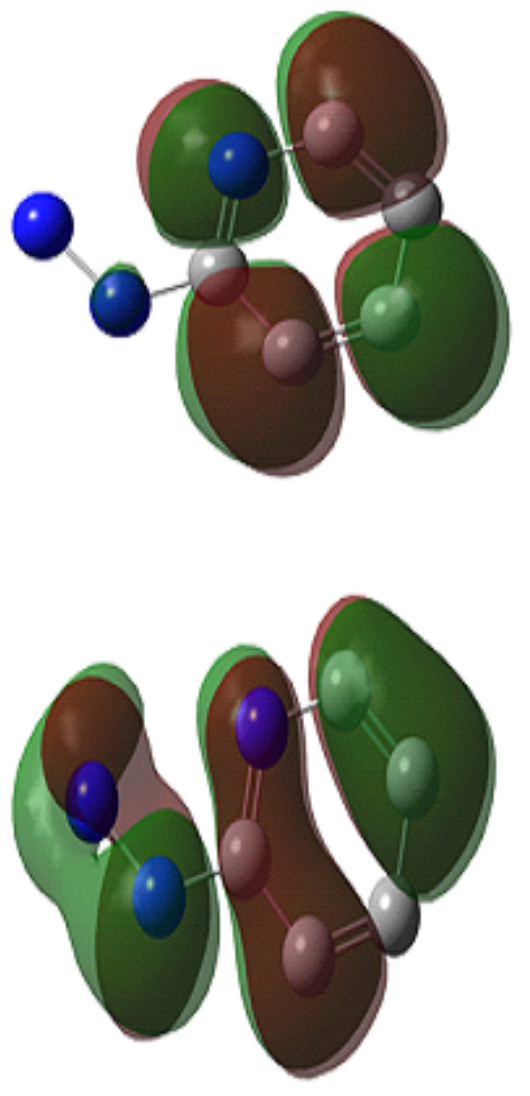

(HPY)

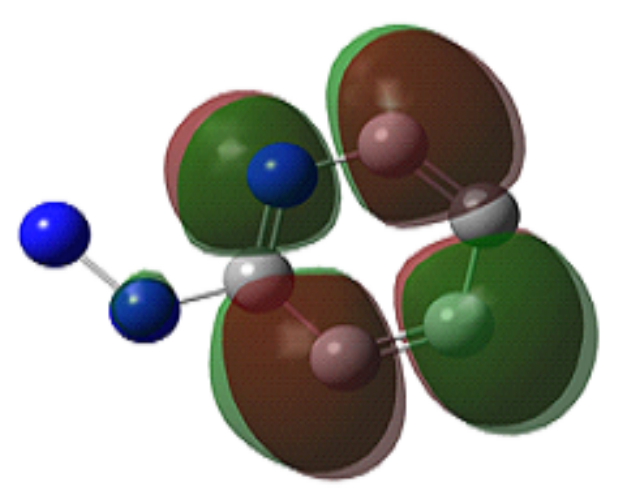

HOMO $=-0.081$

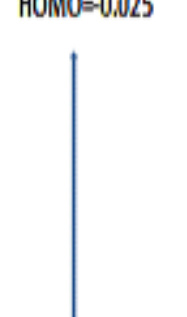

$\triangle E=0.191$

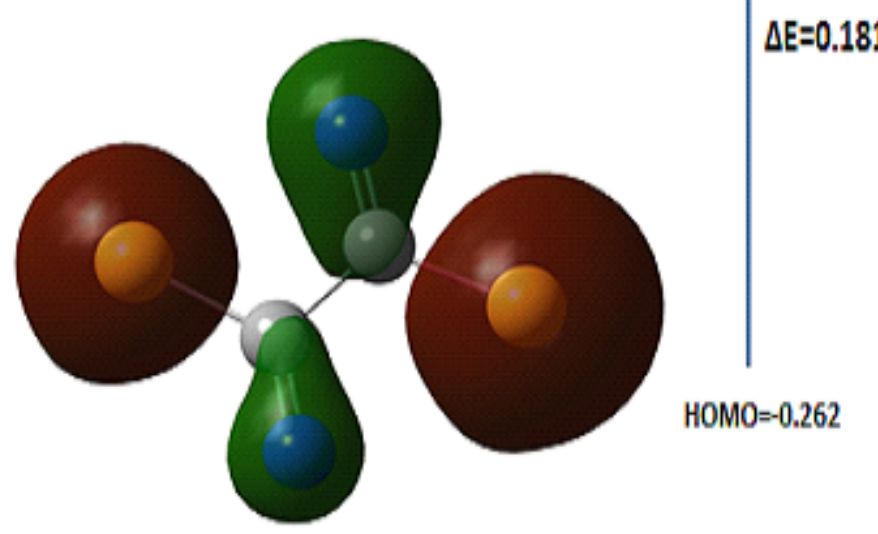

(DTO)

\section{Figure 7}

The HOMO and LUMO molecular orbitals and energy gap of the (HPY) and (DTO) ligands.

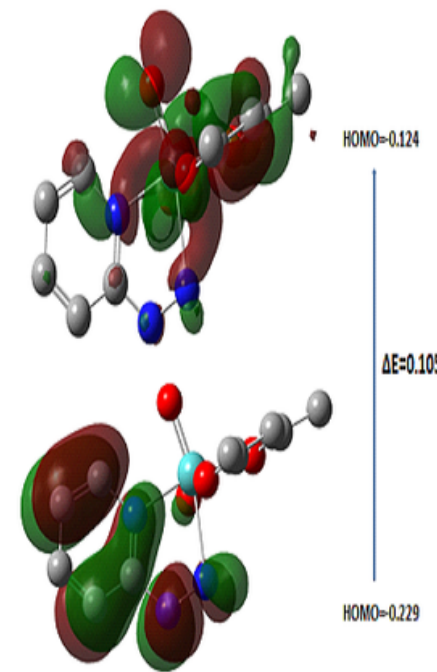

$\left[\mathrm{MoO}_{2}\right.$ (acac)(HPY)] complex
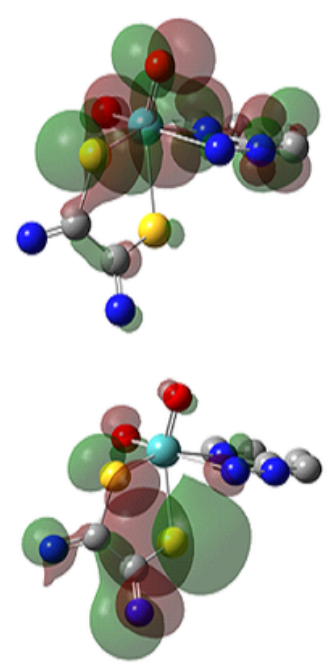

$\left[\mathrm{MoO}_{2}\right.$ (DT O)(HPY)] complex
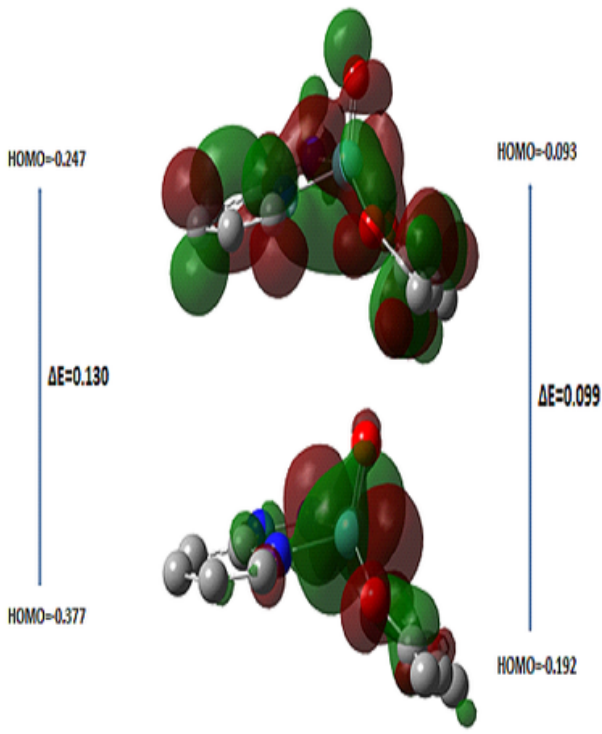

[MoO(acac)(HPY)] complex

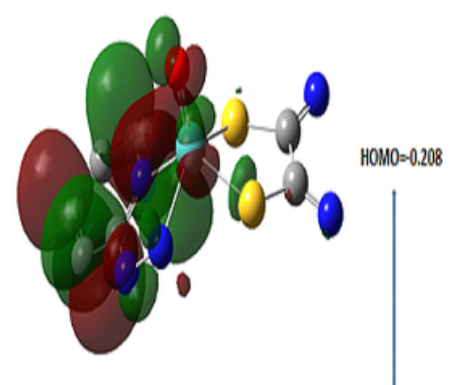

$\Delta E=0.110$

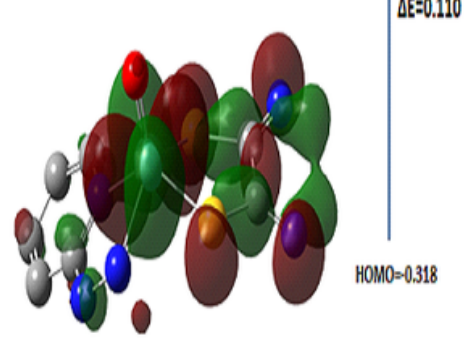

[MoO(DTO)(HPY)] complex

Figure 8 
The HOMO and LUMO molecular orbitals and energy gap of the Mo(VI) and Mo(IV) complexes.

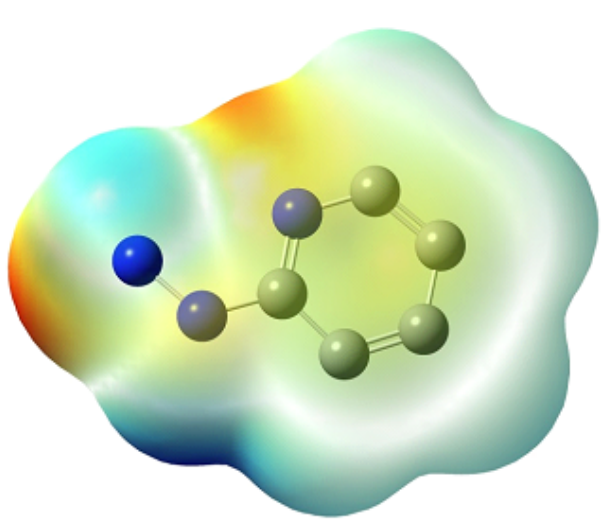

(HPY)

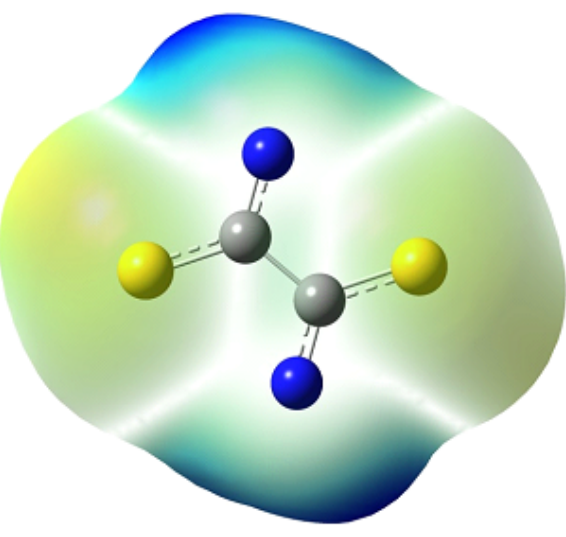

(DTO)

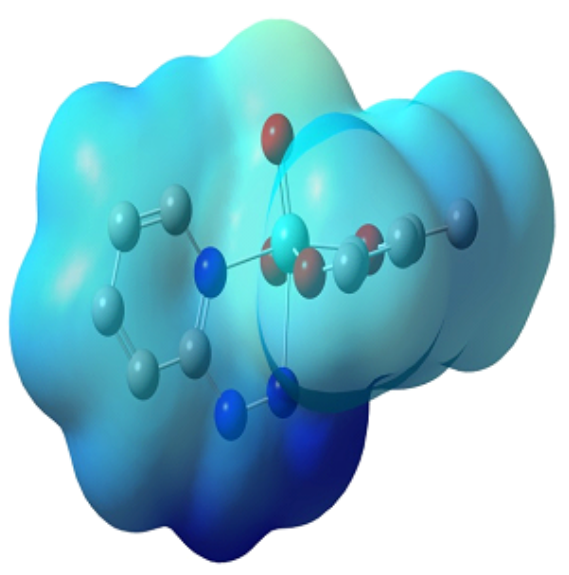

$\left[\mathrm{MoO}_{2}\right.$ (acac)(HPY)] complex

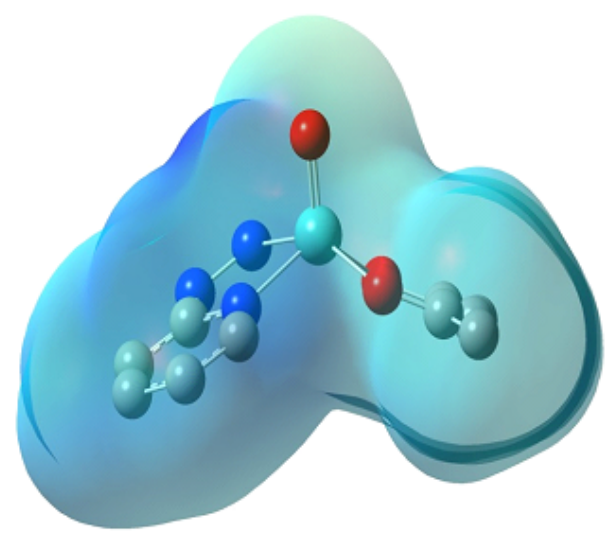

[MoO(acac)(HPY)] complex

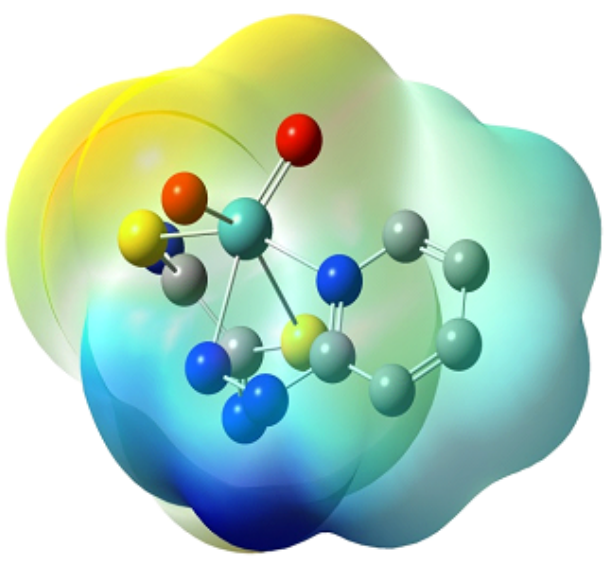

$\left[\mathrm{MoO}_{2}\right.$ (DTO)(HPY)] complex

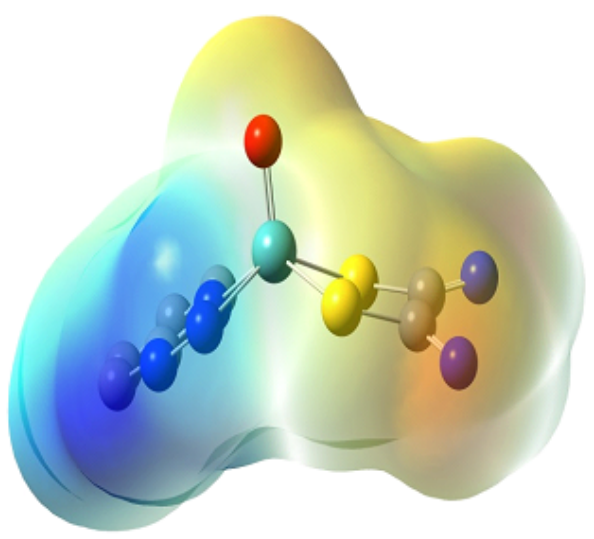

[MoO(DT O)(HPY)] complex

\section{Figure 9}

The MEP (Molecular Electrostatic Potential) of the ligands and $\mathrm{Mo}(\mathrm{VI})$ and $\mathrm{Mo}(\mathrm{IV})$ complexes.

\section{Supplementary Files}


This is a list of supplementary files associated with this preprint. Click to download.

- SupplementaryData.docx 